九州大学学術情報リポジトリ

Kyushu University Institutional Repository

\title{
Cell Division And Elongation In The Decapitated Root Of Vicia Faba L.
}

Kojima, Hitoshi

Botanical Laboratory, Kyushu Imperial University

https://doi.org/10.5109/22567

出版情報: 九州大学大学院農学研究院紀要. 3 (10)，pp.269-301，1933-06. Kyushu Imperial University バージョン :

権利関係 : 
Journal of the Department of Agricu'ture, Kyushu Imperial University, Vol. 3 , No. 10 June 25,1933

CELL DIVISION AND ELONGATION IN THE DECAPITATED ROOT OF VICIA FABA $L^{\gamma}$.

\section{Hitoshi Kojna}

\section{INTRODUCTIÖN}

In my previous papers I have given some accounts of the inves tigations on the relation between cell division and elongation (KojıA, I928, 193I); and the present study, being done on the same subject, is the continuation of them.

The opinion has been entertained thoughtlessly by some that the differentiation of tissue in the root is accelerated, when the growth of the root is inhibited by embedding in gypsum; but in my previous investigation I have ascertained that the progress with regard to speed of cell differentiation in the root embeclded in gypsum is also delayed by its pressure; and also I stated that the elongation and the division of cells are hindered at the same time by the pressure, mechanical or osmotic.

On the other hand, as in the case of the decapitated root, if the further elongation of the root tip is inhibited to some extent, by cutting off its tip, and the further growth, in length or thickness, of the root body is never hindered artificially, then in what relation do the two processes, namely the cell elongation and cell division, pass along? This question is the subject of my study described in this paper.

This investigation was made under the direction of Professor Dr. R. KôkTSU; I wish to take this opportunity to express my very great indebtedness to him, for his guidance and interest. My cordial gratitude is due to En. Professor Dr. K. Fujll, for his kind advice and unceasing encouragement.

I Contritutions from the Rotanical Laboratory, Kyushu Inperial University No. 47. 


\section{JI. MATERIALS AND METHODS}

As the material, young roots of seedling of Vicia Fiaba were used; the experiments were carried on in indoor temperature during the warm season, and in the green house during the winter season, so that the plant might grow in normal or nearly normal conditions. The seeds used in every experiment were nearly uniform in size and weight, and the seeds were got from the same hahitat, though it can not be said that all of them were the same line.

Usually the seeds were soaked in water for about 24 hours and after the seed coat had swelled satisfactorily, they were sowed in a box filled with moist saw dust. When the root of seedlings grew up to suitable length, seedlings, with roots of nearly uniform length and size, were chosen out of many, and used as materials.

To decapitate the root tip a very sharp razor was used and the tip was cut off not in the air but in water.

In usual cases the decapitated roots were brought back to the box of saw dust and grown; namely the seedlings with decapitated roots were embedded carefully in wet saw dust, so that the roots were planted vertically and cotyledons were covered with the saw dust. In cases of culture in water, a wire-netting coated with paraffin, was used, on which the cotyledons were placed, and through the meshes the roots hung down vertically. The wire-netting was placed so as only the roots were dipt in water, and the cotyledons were held in the air.

In order to measure the elongation of the roots, the length was measured not as to the whole root length, but certain definit portions of the root which were determined at the bcginning of the experiment. For this purpose black lines of inclian ink were marked on the surface of the root respectively at the points $4 \mathrm{~mm}, 5 \mathrm{~mm}$ and $10 \mathrm{~mm}$ from the root apex (in Vicia Faba the boundary between the root cap and root proper is not remarkable, so I measured the distance from the root apex) and after certain pre-arranged time the distances between the marks were measured as exactly as possible.

In abbreviation of the description I will use letters $A, B$ and $C$ hereafter: A means the portion between the root apex and the mark of $4 \mathrm{~mm}$ from the apex; $B$, the portion between the marks of $4 \mathrm{~mm}$ and $5 \mathrm{~mm}$ from the root apex; and $\mathrm{C}$, the portion between the marks of $5 \mathrm{~mm}$ and $10 \mathrm{~mm}$ from the root apex. 
Materials for microscopical observations were fixed in Flemming's weaker solution ${ }^{2}$; paraffin sections of $10 \mu$ or $15 \%$, being parallel to the long axis of the root, were prepared and stained with Heidenhaiv's iron haematoxylin. The sections passing as near as possible to the central axis of the root were observed. ZEIss' microscope AA or DD $\times \mathrm{K} 8$, with oc. micrometer $\frac{100}{100} \mathrm{~mm}$ was used.

It has been already mentioned that in the root tip of Vicia Faba mitotic figures are seen most abundantly in the portion within $2 \mathrm{~mm}$ from the apex (cf. PexareK, 1927), and the frequentness of the mitotic divisions is limited in the root tip within $4 \mathrm{~mm}$ from the apex (cf. SchüEPr, 1923); on the other hand the zone, where the elongation is most rapid, is not near the growing point but several millimeters apart from it basipetally (cf. Pferrer's Iandbook, Vol, 2 p. 8).

For that reason, I studied the cell division chiefly on the portion A, namely the part within $4 \mathrm{~mm}$ from the root apex, and the elongation of the cell, on the basipctal portion from that point. Of course the cell division and cell elongation may take place on the same tissue in succession; it might be, therefore, most reliable to observe and compare these two phenomena on every part of the root having ability of growth, but it results naturaily in the enlargement of the work; in order to simplify the work and so to realize the desired object I took the method above mentioned.

The cell length was measured on 4 or 5 sections of each root in the region of the cortex, near the epidermis-at the several portions corresponding to the points 4,5 and $10 \mathrm{~mm}$ from the root apex at the time of decapitation. The length of the cell of each portion of a root was expressed by an average of length of more than 50 cells for each root; the number of length presented in this paper is the average of the lengths of several roots thus obtained, and it is expressed by observed value with micrometer scale; so, if necessary, we can get the real length in $\mu$ by multiplying this by $\frac{160}{69}$.

The frequency of cell division was observed on 10 sections (in some cases 5 sections) of each root ${ }^{3}$. The number of mitotic figures seen in the field-the belt-shaped field, across the long axis of the

\footnotetext{
$=1 \%$ chromic acid $25 \mathrm{cc}+1 \%$ glacial acctic acid loce $+1 \%$ osmic acid roce + water $55 \mathrm{cc}$.

3 The thickness of the section for this purpose was always ro $y$.
} 
root, $\frac{25}{136}(\mathrm{~mm} \leftrightharpoons \mathrm{I} 84 \mu)$ in width and having a length of diameter of the root section at that portion-was counted. The rate of frequency of cell division is expressed by the quotient, dividing the total number of mitotic figures thus found at similar given portions on several sections of a root, by the total amount of the area (calculated in $\mathrm{qmm}$ ) of the fields examined; namely the rate of frequency scen in the tables in this paper is the number of mitotic figures found in 1 qmm of the field.

In connection with the grow:h of cell or tissue of the root the water content in the tissue was also considered. The root used for this purpose was previously cleared away from the saw dust and the moisture was blotted off from its surface. The portion, between the two marks made at 4 and $10 \mathrm{~mm}$ from the root apex at the beginning of the experimcnt, was cut off, then the fresh weight of that portion was measured; afterwards it was dried in an electric oven of about $100^{\circ} \mathrm{C}$ for about 24 hours, cooled in an exicator containing $\mathrm{CaCl}_{2}$ for I-2 hours, then the dry weight was weighed.

\section{I1I. OBSLRVATIONS ON TIIE ELONGATION OF DECAPITATED ROOT}

a) Experiments in saw dust: The roots, respectively decapitated at $\mathrm{I}, 2,3$ and $4 \mathrm{~mm}$ from the root apex, and intact roots were embelded in wet saw dust and grown for about 24 hours. Then the length of cach portion respectively $A, B$ and $C$, was measured, and the amount of the elongation was found. The resuits thus found are given in Tables $I$ and 2 , in which we can see that the elongation of the root, of which a large part of the root tip has been cut off, is generally speaking less than that of the root intact or the root of which a small part of the root tip has been cut off ${ }^{4}$. And comparing the intact root and the $\mathrm{I} \mathrm{mm}$ decapitated root, the latter shows larger elongation than the former, in case of regions $\mathrm{B}$ and $\mathrm{C}$, though there are some exceptional cases; and in $\mathrm{A}$ region, the elongation of the I mm decapitated root is certainly less. With regard to the total length of root, namely $A+B+C$ (basipetal the region $C$, there is

4 likisci, 1884, stated that, regarding the total length of root, the elongation of the root decapitated more than $2 \mathrm{~mm}$ from the root apex is rather pathologically hindered; and BïniNiNG, 1928, found that roots decapitated more than $1.5 \mathrm{~mm}$ from the root apex show less elongation than the intact roots. 
Table I. Elongation of the roots (in saw dust) about 24 hours after decapitation

\begin{tabular}{|c|c|c|c|c|c|c|c|c|}
\hline \multirow{2}{*}{$\begin{array}{c}\text { Experi- } \\
\text { ment }\end{array}$} & \multirow{2}{*}{$\begin{array}{l}\text { Time be- } \\
\text { tween the } \\
\text { operation } \\
\text { and the } \\
\text { ofservation } \\
\text { (in hours) }\end{array}$} & \multirow{2}{*}{$\begin{array}{l}\text { Portion } \\
\text { of which } \\
\text { the elonga- } \\
\text { tion is ob- } \\
\text { served? }\end{array}$} & \multicolumn{2}{|c|}{ Intact roots } & \multicolumn{4}{|c|}{$\begin{array}{l}\text { Roots decapitated at the several } \\
\text { points respectively from the } \\
\text { root apex: }\end{array}$} \\
\hline & & & $\begin{array}{l}\text { Ouserved } \\
\text { yalue } \\
\text { (in } \mathrm{mm} \text { ) }\end{array}$ & $\begin{array}{l}\text { Relative } \\
\text { value }\end{array}$ & $\mathrm{r} \mathrm{mm}$ & $2 \mathrm{~mm}$ & $3 \mathrm{~mm}$ & $4 \mathrm{~mm}$ \\
\hline \multirow[t]{3}{*}{ I } & 24 & A & $26 \cdot 34(8)^{2}$ & 100 & $86.0(10)$ & $49 \cdot 5(6)$ & $8.8(9)$ & - \\
\hline & & $B$ & $4 \% 7 \quad 8\}$ & 100 & $91.0(10)$ & $76.2(6)$ & $61.8(9)$ & $\times 3.6$ (9) \\
\hline & & C & $5.30(10)$ & IOO & $126.4(10)$ & $34 \cdot 3(9)$ & $79.6(9)$ & $44 \cdot 3(9)$ \\
\hline \multirow[t]{3}{*}{ II } & $24 \frac{1}{2}$ & A & $23.27(7)$ & 100 & 9I.I $(7)$ & $60.2(5)$ & I3.3(7) & - \\
\hline & & B & $3 \cdot 34(7)$ & ICO & $226.3(7)$ & $93.4(5)$ & $66.5(7)$ & $17 \cdot 7$ (Io) \\
\hline & & C & $3.65(7)$ & 100 & $120.8(7)$ & $37.8(5)$ & $80.0(6)$ & $46.8(10)$ \\
\hline \multirow[t]{3}{*}{ III } & $22 \frac{1}{2}-23$ & A & $20.22(10)$ & $I \simeq 0$ & $76.6(9)$ & $59.8(\mathbf{1} \mathbf{1})$ & I $1 . \dot{6}(11)$ & - \\
\hline & & $B$ & $2.10(10)$ & 100 & $153.8(\mathrm{~d})$ & $125.7(11)$ & $68.6(11)$ & I6.7(12) \\
\hline & & C & $2.3 \mathrm{C}(10)$ & 100 & $\mathrm{I} 45.2(\mathrm{II})$ & $124 \cdot 3(12)$ & $97 \cdot 4(11)$ & $57 \cdot 0(12)$ \\
\hline \multirow[t]{3}{*}{ IV } & $24:-25$ & A & $26.32(1 \mathrm{i})$ & ioo & $39.0(14)$ & $49.0(14)$ & $7 \cdot 4(14)$ & - \\
\hline & & B & $3.75(10)$ & 100 & ror. $3(13)$ & $73 \cdot 3(14)$ & $52.0(14)$ & $9.9(14)$ \\
\hline & & c: & $4.16(13)$ & IOO & $90.4(14)$ & $80.5(14)$ & $63 \cdot 5(14)$ & $32.9(14)$ \\
\hline \multirow[t]{3}{*}{$\mathrm{V}$} & $23 \frac{1}{2}$ & A & $06.88(8)$ & 100 & $85.8(8)$ & $30.5(8)$ & $4.5(3)$ & - \\
\hline & & B & $3.60(8)$ & 100 & $9 \mathbf{I} . \mathbf{I}(0)$ & $73.2(8)$ & $47.9(7)$ & 9.5 (3) \\
\hline & & C & $4.52 \quad(8)$ & 100 & III.3 $(8)$ & $70.4(3)$ & $53.0(8)$ & $38.3(3)$ \\
\hline \multirow[t]{3}{*}{ Average } & & A & $=4.6 \mathrm{I}$ & 100 & 85.7 & 51.6 & 9.1 & - \\
\hline & & $\mathrm{B}$ & 3.57 & 100 & 112.7 & 83.4 & 59.4 & 13.5 \\
\hline & & C & 3.99 & 100 & II 8.8 & 89.5 & $7^{6} \mathrm{I}$ & $44 \cdot 3$ \\
\hline
\end{tabular}

I $A$ is the portion from the root apex or eut surface to the point $4 \mathrm{~mm}$ from the apex; $B$ is the prortion between the two points respectively 4 and $5 \mathrm{~mm}$ from the root apex; and $\mathrm{C}$ is the portion between the two points respectively 5 and $10 \mathrm{~mm}$ from the ront apex.

2 The number of the roots observed is given in brackets. 
no elongation practically), the elongation of the $1 \mathrm{~mm}$ decapitated root is also less than that of the intact root ${ }^{5}$. The fact that the elongation of regions $\mathrm{B}$ and $\mathrm{C}$ is somewhat accerelated in the $\mathrm{I} \mathrm{mm}$ decapitated root is possibly related to the irritation or hormone action caused by cutting the root tip, yet this is beside the question here.

Table 2. Elongation of the roots (in saw dust) 24 hours after decapitation

\begin{tabular}{|c|c|c|c|c|c|c|}
\hline \multirow{2}{*}{$\begin{array}{c}\text { Experi- } \\
\text { ment }\end{array}$} & \multirow{2}{*}{$\begin{array}{l}\text { Time be- } \\
\text { tween the } \\
\text { operation } \\
\text { and the } \\
\text { observation } \\
\text { (in hours) }\end{array}$} & \multirow{2}{*}{$\begin{array}{l}\text { Portion } \\
\text { of which } \\
\text { the elonga- } \\
\text { tion is ob- } \\
\text { served }\end{array}$} & \multicolumn{2}{|c|}{ Intact roots } & \multicolumn{2}{|c|}{$\begin{array}{l}\text { Roots decapitated ai the } \\
\text { several points respectively } \\
\text { from the root apex: }\end{array}$} \\
\hline & & & $\begin{array}{l}\text { Observed } \\
\text { valuc } \\
\text { (in mmi }\end{array}$ & $\begin{array}{c}\text { Relative } \\
\text { value }\end{array}$ & I $\mathrm{mm}$ & $4 \mathrm{~mm}$ \\
\hline \multirow[t]{3}{*}{ VI } & 24 & A & $2.65 \quad(8)$ & 100 & $85.7 \quad(3)$ & - \\
\hline & & $B$ & $2.20 \quad(8)$ & 100 & $107 \cdot 3(8)$ & r $5.0 \quad(8)$ \\
\hline & & C & $6.42 \quad(8)$ & ICO & $103 \cdot 3 \quad(8)$ & $40.7 \quad(8)$ \\
\hline \multirow[t]{3}{*}{ VII } & 24 & A & $5.95 \quad(4)$ & 100 & $75.6 \quad(4)$ & - \\
\hline & & B & $3.57 \quad$ (4) & 100 & $93.8 \quad(4)$ & $9.8 \quad(4)$ \\
\hline & & C & $6.50 \quad$ (4) & 100 & $113.2 \quad(4)$ & $26.0 \quad(4)$ \\
\hline \multirow[t]{3}{*}{ VIII } & 24 & $A$ & $7.10(14)$ & 100 & $30.7(14)$ & - \\
\hline & & I3 & $4.12(14)$ & 100 & $103.3(14)$ & $3^{I} \cdot 3(14)$ \\
\hline & & C & 5.84 (I 4$)$ & 100 & $118.3(14)$ & $70.4(14)$ \\
\hline \multirow[t]{3}{*}{ IX } & 24 & A & $18.62(\mathrm{II})$ & 100 & 71.4 (10) & - \\
\hline & & $\mathrm{J3}$ & $3.63(\mathrm{II})$ & 100 & IOQ. I $(10)$ & $3^{1 . r}(12)$ \\
\hline & & C & $4.8 \mathrm{I}(\mathrm{II})$ & 100 & $104.6(10)$ & $58.8(\mathrm{I} 2)$ \\
\hline \multirow[t]{3}{*}{ Averagre } & & $\Lambda$ & 8.58 & IOO & 80.4 & - \\
\hline & & $B$ & $3 \cdot 3^{8}$ & IOS & 104.6 & 21.8 \\
\hline & & C & 5.97 & 100 & 109.9 & 49.0 \\
\hline
\end{tabular}

5 FikTscir, 18:4, olserved that roots decapitated at a point within $2 \mathrm{~mm}$ from the root apex elongate to same extent or often a little less than the intact roots; MoLisch, I883, stated that the I mm decapitated root elongates always less than the intact root; Wresner, I $88 \mathrm{I}$, reported that the root, of which the growing point has been cut off, elongates slower than the intact root. 
The above mentioned facts are the cases 24 hours after the decapitation, yet the fact that roots of which the greater portion of the tip has been decapitated elongate slower than the I $\mathrm{mm}$ decapitated roots or intact roots, is also seen in the material 7 hours after the decapitation (Table 3).

Table 3. Elongation of the roots (in saw dust) about 7 hours after decapitation.

\begin{tabular}{|c|c|c|c|c|c|c|c|c|}
\hline \multirow{2}{*}{$\begin{array}{c}\text { Experi- } \\
\text { ment }\end{array}$} & \multirow{2}{*}{$\begin{array}{l}\text { Time be- } \\
\text { tween the } \\
\text { operation } \\
\text { and the } \\
\text { observation } \\
\text { (in hours) }\end{array}$} & \multirow{2}{*}{$\begin{array}{l}\text { Portion } \\
\text { of which } \\
\text { the clonga- } \\
\text { tion is ob- } \\
\text { served }\end{array}$} & \multicolumn{2}{|c|}{ Intact roots } & \multicolumn{4}{|c|}{$\begin{array}{l}\text { Roots decapitated at the several } \\
\text { points respectively from the } \\
\text { root apex: }\end{array}$} \\
\hline & & & $\begin{array}{c}\text { Observed } \\
\text { value } \\
\text { (in nim) }\end{array}$ & $\begin{array}{c}\text { Relative } \\
\text { value }\end{array}$ & I $\mathrm{mm}$ & $2 \mathrm{~mm}$ & $3 \mathrm{~mm}$ & $4 \mathrm{~mm}$ \\
\hline \multirow[t]{3}{*}{$\mathrm{x}$} & \multirow[t]{3}{*}{$7 \frac{1}{3}$} & A & 1. $57(7)$ & 100 & roo.o (9) & $57 \cdot 3(7)$ & $3.9(9)$ & - \\
\hline & & $\mathrm{B}$ & $1.0 \mathcal{S}(\mathcal{B})$ & 100 & $90.1(9)$ & $95 \cdot 4(7)$ & $59.3(9)$ & I $8.5(9)$ \\
\hline & & C & $3.40(10)$ & 100 & $123.8(10)$ & $93.8(9)$ & $76.5(9)^{\prime}$ & $3^{8.5}(9)$ \\
\hline \multirow[t]{3}{*}{$\mathrm{XI}$} & \multirow[t]{3}{*}{7} & A & $0.4 \mathrm{I}(1.3)$ & 100 & $97 \cdot 6(12)$ & - & $2.4(14)$ & - \\
\hline & & B & $0.50(13)$ & 100 & $g^{6} .0(12)$ & - & $34.0(14)$ & $\delta .0(13)$ \\
\hline & & C & $1.65(13)$ & 100 & $93 \cdot 9(12)$ & - & $53 \cdot 9(14)$ & $45 \cdot 5\left(\mathrm{I}_{3}\right)$ \\
\hline \multirow[t]{3}{*}{ XII } & \multirow[t]{3}{*}{7} & $A$ & $0.94(9)$ & 100 & $79.8(10)$ & - & $4 \cdot 3(10)$ & - \\
\hline & & $B$ & $0.84(9)$ & 100 & $91.7(10)$ & - & $42.9(10)$ & $7.1(10)$ \\
\hline & & C & $2.91 \quad(9)$ & $1 \infty$ & $92.1(10)$ & - & $58.1(10)$ & $28.9(10)$ \\
\hline \multirow[t]{3}{*}{ XIII } & \multirow[t]{3}{*}{7} & A & $1.75(12)$ & ICO & $73 \cdot 7(12)$ & - & $10.3(12)$ & - \\
\hline & & B & $1.24(12)$ & 100 & $80.6(12)$ & 一 & $42.7(12)$ & $10.5(12)$ \\
\hline & & C & $2.37(12)$ & 100 & $102.8(12)$ & 一 & $73 \cdot 5(12)$ & $39.0(12)$ \\
\hline \multirow[t]{3}{*}{ XIV } & \multirow[t]{3}{*}{7} & A & $0.80(12)$ & 100 & $98.3(\mathbf{1 2})$ & - & - & - \\
\hline & & $B$ & $0.53(12)$ & IOO & $115.1(12)$ & - & - & $33.9(12)$ \\
\hline & & C & $2.54(12)$ & 100 & $79 \cdot \mathrm{I}(\mathrm{I} 2)$ & - & - & $43.4(12)$ \\
\hline \multirow[t]{3}{*}{ Average } & & A & 1.09 & 100 & 90.0 & - & 6.5 & - \\
\hline & : & $B$ & 0.84 & 100 & 96.3 & - & 44.7 & I 5.6 \\
\hline & & $\mathrm{C}$ & 2.67 & 100 & 96.3 & - & 65.5 & 40.1 \\
\hline
\end{tabular}

But the difference between the elongation of the intact root and the $\mathrm{I} \mathrm{mm}$ decapitated root is not always alike in $\mathrm{C}$ region, in $\mathrm{B}$ region 
the intact root elongates rather more rapidly; and in A region, of course, intact root elongates more rapidly.

Now we consider the expcriments with decapitated roots observed 4 hours after the operation; we can see also in this case that the roots of which the larger portion of the tip has been cut off stretch slower than the intact roots or the $1 \mathrm{~mm}$ decapitated root. There is not a decided differnce between the elongation of the intact root and that of the I $\mathrm{mm}$ decapitated root, yet, speaking in general, the elongation of the intact root is likely to be larger than that of others (Table 4).

Table 4. Elongation of the roots (in saw dust) 4 hours after decapitation

\begin{tabular}{|c|c|c|c|c|c|c|c|}
\hline \multirow{2}{*}{$\begin{array}{c}\text { Experi- } \\
\text { ment }\end{array}$} & \multirow{2}{*}{$\begin{array}{l}\text { Time lie- } \\
\text { tween the } \\
\text { operation } \\
\text { and the } \\
\text { olservation } \\
\text { (in hours) }\end{array}$} & \multirow{2}{*}{$\begin{array}{l}\text { Portion of } \\
\text { which the } \\
\text { eiongation } \\
\text { is observed }\end{array}$} & \multicolumn{2}{|c|}{ Intact roots } & \multicolumn{3}{|c|}{$\begin{array}{l}\text { Roots decapitated at the severai } \\
\text { points respectively from the } \\
\text { root apex: }\end{array}$} \\
\hline & & & $\begin{array}{l}\text { Observed } \\
\text { value } \\
\text { (in } \mathrm{mm} \text { ) }\end{array}$ & $\begin{array}{c}\text { Relative } \\
\text { value }\end{array}$ & $\mathrm{I} \mathrm{mm}$ & $3 \mathrm{~mm}$ & $4 \mathrm{~mm}$ \\
\hline \multirow[t]{3}{*}{$\mathrm{xV}$} & 4 & A & $0.26(\mathrm{II})$ & IOO & $20.6(13)$ & $10.7(14)$ & - \\
\hline & & $B$ & $0.25(12)$ & 100 & $8_{4} . \mathrm{C}(13)$ & $28.0(14)$ & $12.0(16)$ \\
\hline & & C. & $1.37(12)$ & 100 & $88.3\left(1_{3}\right)$ & $56.2(14)$ & $35.8(16)$ \\
\hline \multirow[t]{3}{*}{ XVI } & 4 & $\Lambda$ & $0.50(10)$ & IOS & $7000(10)$ & $2.0(10)$ & - \\
\hline & & B & 0.22 (I0) & 100 & $127.3(10)$ & $27.3(10)$ & $27.3(10)$ \\
\hline & | & C & 1.09 (In) & 100 & 99.1 (10) & $58.7(10)$ & $34.9(10)$ \\
\hline \multirow[t]{3}{*}{ XVII } & 4 & A & $0.45(14)$ & 100 & $95.6(16)$ & $6.7(16)$ & - \\
\hline & & $B$ & $0.28(14)$ & 100 & $100.0(16)$ & $39.3(16)$ & I7.9 (I4) \\
\hline & & C. & I. 50 (I 4$)$ & 100 & $104.7(16)$ & $40.7(16)$ & $36.7(14)$ \\
\hline \multirow[t]{3}{*}{ XVIII } & 4 & $\Lambda$ & $0.39(\mathbf{I} \mathbf{I})$ & 100 & $110.3(9)$ & 10.3 (II) & - \\
\hline & & B & $0.40($ I I ) & I0O & 80.0 (9) & $52.5(\mathrm{I} \mathrm{I})$ & $20.0(\mathrm{II})$ \\
\hline & 10 & $\mathrm{C}$ & $1.60(\mathrm{II})$ & 100 & $100.0(\mathrm{II})$ & $60.6(1 \mathrm{I})$ & $37 \cdot 5$ (II) \\
\hline \multirow[t]{3}{*}{ Average } & & A & 0.41 & 100 & 76.1 & $7 \cdot 4$ & 一 \\
\hline & † & B & 0.29 & 100 & 97.3 & $3^{6.8}$ & 19.3 \\
\hline & 1 & C & 1.39 & 100 & 98.0 & $54 . \mathrm{I}$ & 36.2 \\
\hline
\end{tabular}

b) Experiment in water: The similar experiments as above mentioned have been done, not in saw dust but in water. The roots, 
decapitated as well as intact, are grown in water for about 24 hours (Table 5); under these several experiments the results of observation can not be said to be exactly parallel, as seen in the cases in saw dust. Concerning $\mathrm{C}$ region, sometimes the $4 \mathrm{~mm}$ decapitated roots show less elongation than the intact roots, but in other cases, on the contrary; yet generally speaking there is likely to be no clear difference between them (the average elongation of the intact root : that of the $4 \mathrm{~mm}$ decapitated root $=100: 104)$. Regarding $C$ region, in

Table 5. Elongation of the roots (in water) 24 hours after decapitation

\begin{tabular}{|c|c|c|c|c|c|c|c|}
\hline \multirow{2}{*}{$\begin{array}{l}\text { Experi- } \\
\text { ment }\end{array}$} & \multirow{2}{*}{$\begin{array}{l}\text { Time be } \\
\text { tween the } \\
\text { operation } \\
\text { and the } \\
\text { observation } \\
\text { (in hours) }\end{array}$} & \multirow{2}{*}{$\begin{array}{l}\text { Portion } \\
\text { of which } \\
\text { the elong;- } \\
\text { tion is ob- } \\
\text { served }\end{array}$} & \multicolumn{2}{|c|}{ Intact roots } & \multicolumn{3}{|c|}{$\begin{array}{l}\text { Roots decapitated at the several } \\
\text { points respectively from the } \\
\text { root apex : }\end{array}$} \\
\hline & & & $\begin{array}{l}\text { Observed } \\
\text { value } \\
\text { (in min) }\end{array}$ & $\begin{array}{c}\text { Relative } \\
\text { value }\end{array}$ & $\mathrm{I} \mathrm{mm}$ & $3 \mathrm{~mm}$ & $4 \mathrm{~mm}$ \\
\hline \multirow[t]{3}{*}{ XIX } & 24 & $\Lambda$ & $12.36(19)$ & 100 & $120.1(22)$ & $32.0(21)$ & - \\
\hline & & $B$ & $3.39(19)$ & roo & $117.7(22)$ & $105.3(21)$ & $64.9(20)$ \\
\hline & & C: & $4.10(20)$ & 100 & $110.7(20)$ & $104.2(20)$ & $108.5(20)$ \\
\hline \multirow[t]{3}{*}{$\mathrm{xx}$} & 24 & A & 7.24 (9) & ros & $102.5 \quad(9)$ & $37.6 \quad$ (9) & - \\
\hline & & $B$ & 4.08 (9) & IOO & $82.0 \quad(9)$ & $68.1 \quad(9)$ & $62.7(10)$ \\
\hline & & C & $4 \cdot 3^{6}(14)$ & 100 & $133.0(15)$ & $116.7(14)$ & $141.3(16)$ \\
\hline \multirow[t]{3}{*}{$\mathrm{XXI}$} & 24 & $A$ & $4.01(16)$ & 100 & $133.2(10)$ & $963(14)$ & - \\
\hline & & B & $2.66(16)$ & 100 & $107.9(18)$ & I03. $(\mathrm{I} 4)$ & $67 \cdot 3(16)$ \\
\hline & & C & $3.86(16)$ & 100 & $102.6(18)$ & $1 \times 7.9(15)$ & $92.2(16)$ \\
\hline \multirow[t]{3}{*}{ XXII } & 24 & $\lambda$ & $8.99(14)$ & 100 & I $12.6(14)$ & -- & - \\
\hline & & si & $3.9^{1}(14)$ & 100 & $117.1(14)$ & - & $63.2(15)$ \\
\hline & & C: & $5.85(15)$ & 100 & $109.6(14)$ & - & $81.2(15)$ \\
\hline \multirow[t]{3}{*}{ XXIII } & 24 & $\Lambda$ & $10.82(13)$ & too & $310.7(12)$ & - & - \\
\hline & & B & $3 \cdot 70(13)$ & 100 & $86.5(12)$ & - & 78.4 (1 I ) \\
\hline & & C & $5.6 \pm(13)$ & IOO & $75.8(\mathrm{r} 2)$ & - & 96.4 (Ix) \\
\hline \multirow[t]{3}{*}{ Average } & & A & 8.68 & 100 & I 5.9 & $55 \cdot 3$ & - \\
\hline & & . B & 3.55 & 100 & $10 \geq .4$ & $9^{2.4}$ & $67 \cdot 3$ \\
\hline & & C & $4 \cdot 7^{6}$ & 100 & 106.3 & 1129 & 103.9 \\
\hline
\end{tabular}


general, the $3 \mathrm{~mm}$ decapitated roots elongate rather more rapidly than the intact roots. And comparing the $1 \mathrm{~mm}$ decapitated root with the intact root there are not such definite differences between their elongations as regards $C$ region and $B$ region, but within $A$ region the $1 \mathrm{~mm}$ decapitated root shows larger elongation. Hence as to the sum of these 3 regions $(A+B+C)$ the $1 \mathrm{~mm}$ decapitated roots elongate more rapidly ${ }^{6}$.

Table 6. Elongation of the roots (in water) 7 hours after decapitation

\begin{tabular}{|c|c|c|c|c|c|c|c|c|}
\hline \multirow{2}{*}{$\begin{array}{c}\text { Experi- } \\
\text { ment }\end{array}$} & \multirow{2}{*}{$\begin{array}{l}\text { Time le- } \\
\text { tween the } \\
\text { operation } \\
\text { and the } \\
\text { oljervation } \\
\text { (in hours) }\end{array}$} & \multirow{2}{*}{$\begin{array}{l}\text { Portion } \\
\text { of which } \\
\text { the elongh- } \\
\text { tion is ob- } \\
\text { served }\end{array}$} & \multicolumn{2}{|c|}{ Intact roots } & \multicolumn{4}{|c|}{$\begin{array}{l}\text { Roots decapitated at the several } \\
\text { points respectively from the } \\
\text { root apex: }\end{array}$} \\
\hline & & & $\left|\begin{array}{c}\text { Olyserved } \\
\text { value } \\
\text { (in } \mathrm{mm} \text { ) }\end{array}\right|$ & $\begin{array}{c}\text { Relative } \\
\text { value }\end{array}$ & $1 \mathrm{~mm}$ & $2 \mathrm{~mm}$ & $3 \mathrm{~mm}$ & $4 \mathrm{~mm}$ \\
\hline \multirow[t]{3}{*}{ XXIV } & 7 & A & $0.67(14)$ & 100 & 143.3 (I4) & - & $70.1(14)$ & - \\
\hline & & $\pi$ & $0.53(14)$ & 100 & $147.2(14)$ & - & I $54.7\left(\mathrm{r}_{4}\right)$ & $105.7(15)$ \\
\hline & & $\mathrm{C}$ & $2.80(14)$ & 100 & $103.9(14)$ & - & $130.4(14)$ & 120.7 (15) \\
\hline \multirow[t]{3}{*}{$\mathrm{XXV}$} & 7 & $\Lambda$ & $0.7 \mathrm{C}(12)$ & 100 & $101.4(12)$ & - & - & - \\
\hline & & $B$ & $0.43(12)$ & 100 & $109 \cdot 3(12)$ & - & - & $90.7(13)$ \\
\hline & & C & $2 \cdot 1(1(12)$ & 100 & $104.6(12)$ & - & - & IOU. $5(13)$ \\
\hline \multirow[t]{3}{*}{ XXVI. } & 7 & A & $0.43(12)$ & 100 & I $46.5(\mathrm{r} 3)$ & II $4.0(12)$ & - & - \\
\hline & & $B$ & $0.43(12)$ & 100 & $86.0(13)$ & $100.0(12)$ & - & $86.0(12)$ \\
\hline & & C & $T .90(12)$ & roo & $106.8(13)$ & $93.7(12)$ & - & $95: 3(12)$ \\
\hline \multirow[t]{3}{*}{$\Lambda$ verage } & & $\Lambda$ & 0.60 & 100 & 130.4 & - & 一 & - \\
\hline & & B & 0.45 & 100 & I 14.2 & - & - & $94 . \mathrm{I}$ \\
\hline & & C & 2.29 & IOO & IC5.I & 一 & - & $10_{7} \cdot 5$ \\
\hline
\end{tabular}

The experiments, in water for about 7 hours, show that, in general, the $4 \mathrm{~mm}$ decapitated root has a little more rapid elongation than the intact root, in $\mathrm{C}$ region; and the former elongates in less degree than the intact root as regards $B$ region (Table 6). The $1 \mathrm{~mm}$ decapitated root elongates more rapidly than the intact root, in general, in every region.

\footnotetext{
6 This fact coincides with the resuits of Wiesvis (10\%4), who stated that the $1 \mathrm{~mm}$ decapitated root cultured in water elongates far more ripidly than the intact root by maize root.
} 
Roots cultured in water for 4 hours were also examined. As a whole, the rate of elongation of the $3 \mathrm{~mm}$ decapitated roots as well as the $4 \mathrm{~mm}$ decapitated roots in $\mathrm{C}$ region is larger; and as to $\mathrm{I}$ region, with some exceptions, it is also larger. The elongation of the $\mathrm{I} \mathrm{mm}$ decapitated root is always larger than the intact root as regards the total length of the root (Table 7).

Table 7. Elongation of the roots (in water) 4 hours after decapitation

\begin{tabular}{|c|c|c|c|c|c|c|c|c|}
\hline \multirow{2}{*}{$\begin{array}{c}\text { Experi- } \\
\text { ment }\end{array}$} & \multirow{2}{*}{$\begin{array}{l}\text { Time be- } \\
\text { tween the } \\
\text { operation } \\
\text { and the } \\
\text { observation } \\
\text { (in hours) }\end{array}$} & \multirow{2}{*}{$\begin{array}{l}\text { Portion } \\
\text { of which } \\
\text { the elonga } \\
\text { tion is ol- } \\
\text { served }\end{array}$} & \multicolumn{2}{|c|}{ Intact roots } & \multicolumn{4}{|c|}{$\begin{array}{l}\text { Roots decapitated at the several } \\
\text { points respectively from the } \\
\text { root apex: }\end{array}$} \\
\hline & & & $\begin{array}{c}\text { Observed } \\
\text { value } \\
\text { (in } \mathrm{mm} \text { ) }\end{array}$ & $\begin{array}{c}\text { Relative } \\
\text { value }\end{array}$ & $1 \mathrm{~mm}$ & $2 \mathrm{~mm}$ & $3 \mathrm{~mm}$ & $4 \mathrm{~mm}$ \\
\hline \multirow[t]{3}{*}{ XXVII } & \multirow[t]{3}{*}{4} & A & $0.42(12)$ & 100 & $142.9(13)$ & - & $69 . c\left(\mathrm{I}_{3}\right)$ & - \\
\hline & & B & $0.25(12)$ & 100 & $120.0\left(I_{3}\right)$ & - & $133.2(13)$ & $124 \circ(12)$ \\
\hline & & C. & $10.7(1 \mathrm{I})$ & 100 & $1 \times 7.8(13)$ & - & I $2.1(\mathrm{r} z)$ & $119.6(12)$ \\
\hline \multirow[t]{3}{*}{ XXVIII } & \multirow[t]{3}{*}{4} & $\Lambda$ & $0.30(14)$ & 100 & $140.0(14)$ & - & $50.0(14)$ & - \\
\hline & & B & $0.24(14)$ & 100 & $104.2(14)$ & - & $1.37 .5(14)$ & $87.5(14)$ \\
\hline & & C & $1.30\left(I_{4}\right)$ & 100 & $117.7(14)$ & - & $103.5(14)$ & $109.2(14)$ \\
\hline \multirow[t]{3}{*}{ XXIX } & \multirow{3}{*}{4} & A & $0.14(13)$ & 100 & $207.1(13)$ & - & $142.9(\mathrm{I} 3)$ & - \\
\hline & & Ii & $0.1 \delta_{(13)}^{\prime}$ & 100 & $122.2(13)$ & - & $150.0\left(\mathrm{I}_{3}\right)$ & $127.8(13)$ \\
\hline & & C. & I.I $7\left(1_{3}\right)$ & 100 & III.I $(13)$ & - & $118.8\left(x_{3}\right)$ & $\ln 1 . \mathrm{r}(\mathrm{1} 3)$ \\
\hline \multirow[t]{3}{*}{$\mathrm{XXX}$} & \multirow[t]{3}{*}{4} & $\Lambda$ & $0.53(12)$ & 100 & $120 \cdot 8(13)$ & I 26.413 & - & $\cdots$ \\
\hline & & 13 & $0.35(12)$ & ICO & $\mathbf{1} 28.6(13)$ & $122.9(13)$ & - & $102.9(12)$ \\
\hline & & C & $1.73(12)$ & IOC & $100.6(13)$ & $97.1(13)$ & - & 102.9 (12) \\
\hline \multirow[t]{3}{*}{ Average } & & A & 0.35 & 100 & 152.7 & 一 & $87 \cdot 3$ & - \\
\hline & & B & 0. 26 & 100 & 118.7 & - & 140.2 & I 10.6 \\
\hline & & C & 1.32 & 100 & I I I .8 & 一 & I 1 I.3.1 & 1107 \\
\hline
\end{tabular}

c) Comparing the above mentioned two series of experiments, we can find that in the series in saw dust, the results of each experiment are almost parallel, namely, it may be said that the more largely decapitated roots, either in $\mathrm{A}, \mathrm{B}$ or $\mathrm{C}$, elongate less; while in the cases of series in water the results of individual experiments are 
variable, and in these cases, for example, the $3 \mathrm{~mm}$ and $4 \mathrm{~mm}$ decapitated roots 4 hours after the cutting, in regions $B$ and $C$, the $4 \mathrm{~mm}$ decapitated root 7 hours after the decapitation, in $C_{\text {r }}$ region, the $3 \mathrm{~mm}$ decapitated root 24 hours after the decapitation, in $C$ region, etc., the elongation of the decapitated roots is rather grcatcr. And the $1 \mathrm{~mm}$ decapitated root cultured in saw dust shows greater elongation than that of the intact root in regions $B$ and $C$, and in $A$ region the former is less in the rate of elongation, while the $1 \mathrm{~mm}$ decapitated root cultured in water always elongates to a larger extent (either in $\mathrm{A}, \mathrm{B}$ or C).

In the decapitated surface the cells being cut are exposed, so the conditions of the tissues near the cut are quite contracy to those of the tissues in the normal root. The influence of the outside conditions upon the water content of the tissue of the root is, therefore, quite different in this case. As a matter of fact, the cut surface of the root cultured in saw dust is adjoined to moisture or grains of saw dust, as the case may be; and in other and more common cases, the cut surface is exposed to the air with moisture, kept at saturation point, contained in the space among the grains of saw dust. On the other hand, in the cases of the roots, cultured in water, it goes without saying that the cut surfaces are always covered with water. It must be possible to attribute the majority of these discrepancies between the results, obtained in the experiments in saw dust and in water, to the influence of water. The fact that the decapitated root in water showed greater elongation may be considered as the results of superfluous elongation caused by the absorption of excess of water through the cut surface. On this account, we have scen that the regions $B$ and $C$ the decapitated root, in water, elongated rapidly within 4 hours after cutting, but decreased its rate with progress of time, namely 7 hours and 24 hours after decapitation; and it perhaps reveals to us the truth that the rapidity of elongation within 4 hours is not the growth, in real sense, but only the symptom of growth disturbed by the superfluous elongation. In the same manner, we may think that the rapid elongation in A region of the I $\mathrm{mm}$ decapitated root is due to the excess of water.

Of the two methods of experiment above mentioned, the one has a defect in the loss of water through the cut surface, and the other, a superfluous elongation by excess of water; both of them have advantages and clisadvantages, yet we can see from these experiments, the state of elongation of the decapitated roots even though it is not 
so exact. Consequently, the relation between the elongation of the root and that of the cell can be seen by either of the two methods of experiment; and jn order to observe this point of question I used the materials cultured in saw dust.

\section{OBSERVATION OF CELLS IN THE GROWING ZONE OF THE IDECAPITATED ROOT}

As I have already mentioned in $\S 2$ (on the methods), the observation on the elongation of individual cells was made on the basipetal portions from the point $4 \mathrm{~mm}$ from the root apex.

Selecting several roots out of the materials of Fixp. II, Table I (i.e. roots $24 \frac{1}{2}$ hours after the decapitation), that had elongated at a nearly average rate of elongation in that experiment of growth, and fixing and preparing them for the microscopic use, I measured the length of the cells (Table 8 , Series 1). And it was found that the I $\mathrm{mm}$ decapitated root and the intact root had ncarly the same length of cell; the length of cell of the $3 \mathrm{~mm}$ decapitated root at the portions corresponding to the points $4 \mathrm{~mm}$ and $5 \mathrm{~mm}$ from the root apex at the time of the operation, is a little shorter; and the length of cell of the $4 \mathrm{~mm}$ decapitated root, in the portion corresponding to the point $5 \mathrm{~mm}$ from the root apex at the time of the operation, is very short, nearly the half of that in the roots, being decapitated at $1 \mathrm{~mm}$ or intact, at the corresponding portion.,

Table 8. Length of cell in the roots (in saw dust) about 24 hours after decapitation

Series I.

\begin{tabular}{|c|c|c|c|c|c|c|}
\hline \multirow[t]{2}{*}{$-5-1-1$} & & \multicolumn{2}{|c|}{ Intact roots } & \multicolumn{3}{|c|}{$\begin{array}{l}\text { Roots decapitated at the several } \\
\text { points respectively from the } \\
\text { root apex : }\end{array}$} \\
\hline & & $\begin{array}{c}\text { Observed } \\
\text { value }^{\mathrm{I}}\end{array}$ & $\begin{array}{c}\text { Relative } \\
\text { value }\end{array}$ & $\mathrm{I} \mathrm{mm}$ & $3 \mathrm{~mm}$ & $4 \mathrm{~mm}$ \\
\hline Fo. of roots olserved & & 7 & & 5 & 5 & 6 \\
\hline $\begin{array}{l}\text { Cell lengths, measurcd } 24 \frac{1}{2} \\
\text { hours after the decapitation, } \\
\text { at the points corresponding } \\
\text { to the points apart from the } \\
\text { apex of root at the time of } \\
\text { the operation, respectively: }\end{array}$ & $4 \mathrm{~mm} \mathrm{r}$ & $\begin{array}{l}14.32(707)^{2} \\
14.19(834)\end{array}$ & 100 & $\begin{array}{l}\operatorname{I0x} .5(323) \\
\operatorname{IOI} .6(353) \\
98.1(349)\end{array}$ & $\begin{array}{l}68.4(649) \\
75.9(666) \\
91 . \mathrm{x}(535)\end{array}$ & $\begin{array}{c}- \\
56.2(464) \\
98.5(367)\end{array}$ \\
\hline
\end{tabular}


Series 2 .

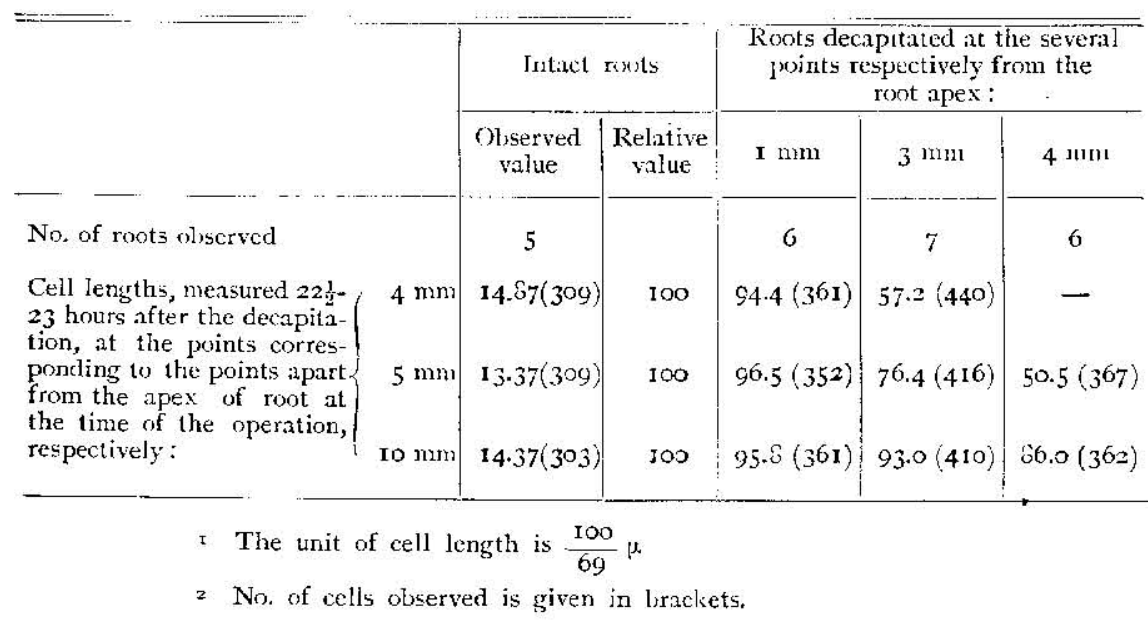

The results obtained by measuring on the cell length in several roots, selected out of the scedlings of Exp. III, Table I (i.e. materials about 23 hours after the decapitation), having the rate of elongation nearly equal to the average elongation, are nearly identical to those above mentioned (Table 8 , Series 2).

In the same manner I studied the materials (out of the roots of Exp. XII, Table 3) 7 hours after decapitation. The length of cells in the $3 \mathrm{~mm}$ decapitated root or the $4 \mathrm{~mm}$ decapitated root in smaller to some degree than that of the intact root or the $1 \mathrm{~mm}$ decapitated root (Table 9), in this respect the result is identical to that of experiments 24 hours after the decapitation.

Table 9. Length of cell in the roots (in saw dust) 7 hours after the decapitation

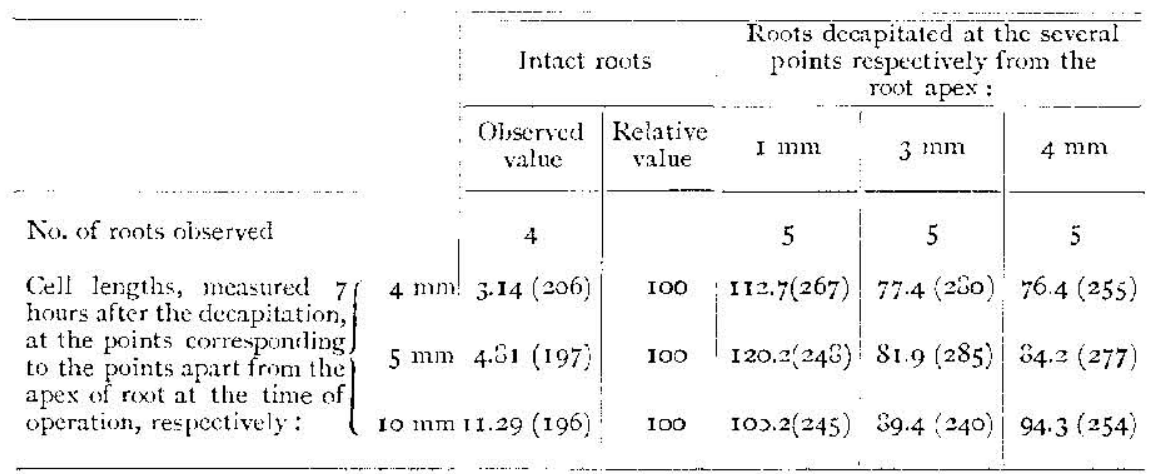


In the materials 4 hours after the decapitation (out of the material of Exp. XV, Table 4), there is not such a remarkable difference between the cells of the different kind of roots (Table ro) (except in the smallness of cell length of the $3 \mathrm{~mm}$ decapitated root, at $5 \mathrm{~mm}$ point) as seen in the materials of the experiments 24 hours and 7 hours after the decapitation. This is explained by the reason that as the time of elongation is too short, the differences of the length are not remarkable enough to be measured.

Table Io. I.ength of cell in the roots (in saw dust) 4 hours after the decapitation

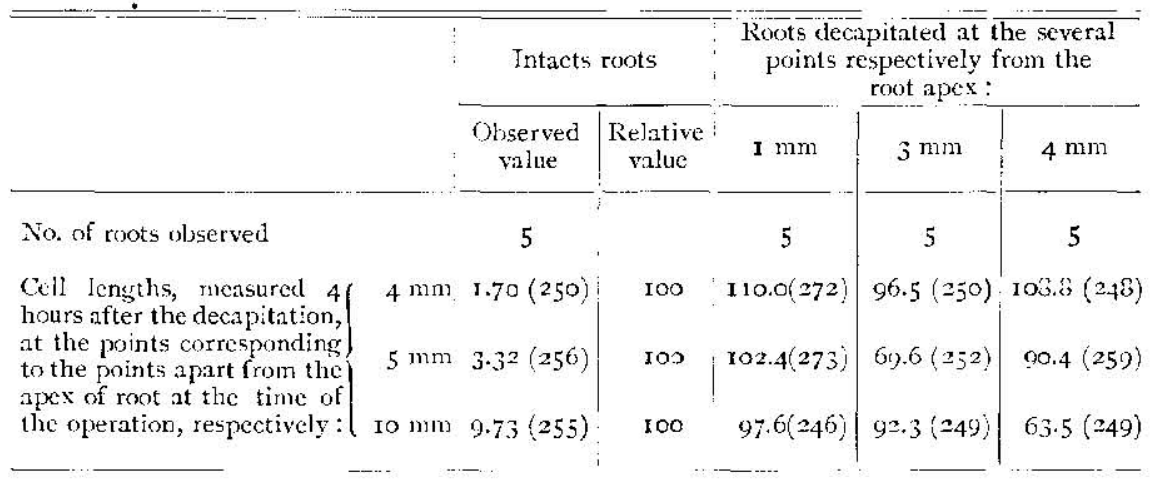

From the observations on the cell length, taking into consideration the results of experiments in saw dust as well as in water, we find that the difference between the cell length of the different kind of roots is parallel to the difference in the elongation of the roots.

\section{OBSERVATIONS OF CELL, DIVISION IN THE ROOT IIP OF THE DECAHTTATEN ROOT}

Observation of cell division was made mainly in the portion within $4 \mathrm{~mm}$ from the root apex as above mentioned. Measuring the frequency of cell division in the root, 4 hours after the decapitation (material of Exp. XV, Table 4, selected by their rate of elongation, namely the roots elongated in a rate nearly equal to that of average elongation of the whole roots of the experiment) we can get the results shown in Table II. In the intact root the frequency of cell division is maximum at the portion $1.0 \mathrm{~mm}$ from the root apex, and from that 
point upward the rate decreases gradually; in the $1 \mathrm{~mm}$ decapitated roots the maximum of the rate is at $0.5 \mathrm{~mm}$ from the decapitated surface-and the absolute value of the maximum rate in the $I \mathrm{~mm}$ decapitated root is far less than that of the intact root-and from that point the rate decreases; and in the $3 \mathrm{~mm}$ decapitated root the frequency of cell division in the portion near the cut surface as well as that of the basipetal is always small; the region observable in this root is $3 \mathrm{~mm}$ from the root apex to the basipetal and as there is no more frequency of cell division, it is natural that there arises no remarkable variation of the frequency of cell division, by the cutting.

The roots, used as the material of this observation, elongated during 4 hours after decapitation, in an average, as follows: the intact root $0.28 \mathrm{~mm}$, the $[\mathrm{mm}$ decapitated root, $0.08 \mathrm{~mm}$ and the $3 \mathrm{~mm}$ decapitated root, $0.03 \mathrm{~mm}$. So not taking into consicleration the enlongation of each of the different kind of roots, we may rearrange the curves as in Fig. I, namely placing the portion most contiguous to the cut surface of the $1 \mathrm{~mm}$ decapitated root (i.e. o) to the point $1.0 \mathrm{~mm}$ from the root apex in the intact root, and the points $O$ of the

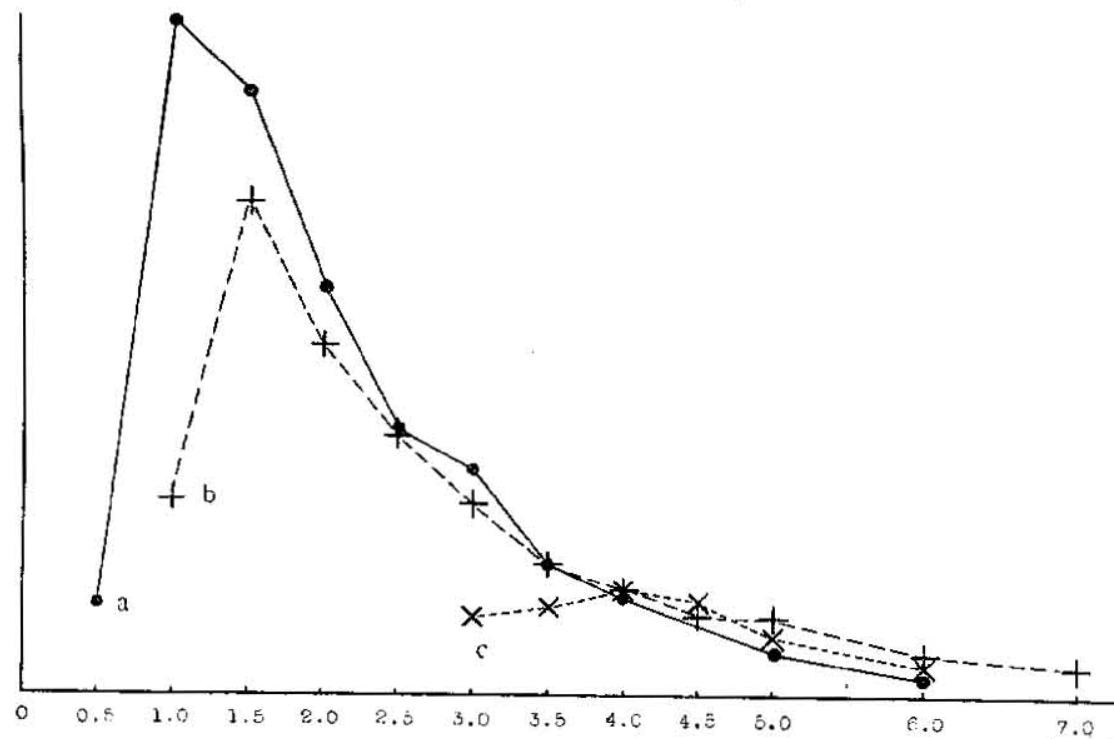

Fig. I. lirequency of cell division of the decapitated roots (4 hours after decapita. tion, in comparison with that of the intact root. Ordinates represent the frequency of cell division; alscissa, distance (in $\mathrm{mm}$ ) from the apex of the intact root, at the time of measurement. Curve a, the intact root; $b$, the $1 \mathrm{~mm}$ decapitated root; $c$, the $3 \mathrm{~mm}$ decapitated root. 
Table 11. Frequency of cell division at the several points in the root (in saw dust) 4 hours after decapitation, indicated by the number of mitotic figures found in the ficld of I qmm (The area of the field examined is given in brackets (in s.mm))

\begin{tabular}{|c|c|c|c|c|c|c|c|c|c|c|c|}
\hline & \multicolumn{11}{|c|}{$\begin{array}{l}\text { Frequency of coll division at the listance from the root apex or cut surface } \\
\text { (at the time of olscrvation) of: }\end{array}$} \\
\hline & o & $0.5 \mathrm{~nm}$ & I.O $\mathrm{mm}$ & $1.5 \mathrm{~mm}$ & $2.0 \mathrm{~mm}$ & $2.5 \mathrm{~mm}$ & $3.0 \mathrm{~mm}$ & $3.5 \mathrm{~mm}$ & $4.0 \mathrm{~mm}$ & $5.0 \mathrm{~mm}$ & $6.0 \mathrm{~mm}$ \\
\hline $\begin{array}{l}\text { Intact root } \\
\text { Averrge of } 5 \text { rcots }\end{array}$ & - & $\begin{array}{l}(3.06 \\
(3.81)\end{array}$ & $\begin{array}{r}136.86 \\
(4.27)\end{array}$ & $\begin{array}{r}122.14 \\
(4.86)\end{array}$ & $\begin{array}{c}82.24 \\
(5 \cdot 37)\end{array}$ & $\begin{array}{l}5.3 .42 \\
(5.74)\end{array}$ & $\begin{array}{l}45.56 \\
(5.95)\end{array}$ & $\begin{array}{c}26.28 \\
(6.03)\end{array}$ & $\begin{array}{l}19.90 \\
(6 . c 8)\end{array}$ & $\begin{array}{c}8.78 \\
(6.09)\end{array}$ & $\begin{array}{l}3.22 \\
(6.08)\end{array}$ \\
\hline $\begin{array}{l}\text { I mm deca pitated root } \\
\text { Avernste of } 5 \text { roots }\end{array}$ & $\begin{array}{l}39.60 \\
(4.64)\end{array}$ & $\begin{array}{r}100.32 \\
(5.2 .3)\end{array}$ & $\begin{array}{l}70.20 \\
(5.75)\end{array}$ & $\begin{array}{l}52.90 \\
(6.06)\end{array}$ & $\begin{array}{l}38.72 \\
(6.28)\end{array}$ & $\begin{array}{l}26.20 \\
\left(6.3^{1}\right)\end{array}$ & $\begin{array}{l}20.78 \\
(6.28)\end{array}$ & $\begin{array}{l}16.06 \\
(6.30)\end{array}$ & $\begin{array}{l}15.38 \\
(6.32)\end{array}$ & $\begin{array}{c}8 . c 6 \\
(6.28)\end{array}$ & $\begin{array}{l}5.88 \\
(6.34)\end{array}$ \\
\hline $\begin{array}{l}3 \mathrm{~mm} \text { decipiliated root } \\
\text { Azerage of } 5 \text { routs }\end{array}$ & $\begin{array}{l}15.44 \\
(5.30)\end{array}$ & $\begin{array}{l}\mathbf{I} 7.68 \\
(5.58)\end{array}$ & $\begin{array}{l}20.84 \\
(5.75)\end{array}$ & $\begin{array}{l}18.20 \\
(5.81)\end{array}$ & $\begin{array}{l}11.16 \\
(5.82)\end{array}$ & - & $\begin{array}{l}5.84 \\
(5.80)\end{array}$ & & & & \\
\hline
\end{tabular}

Table 12. Frequency of cell division at several points in the root (in saw dust) 7 hours after decapitation, indicated by the number of mitotic figures found in the field of $\mathrm{r}$ qmm (The area of the field examined is given in brackets (in $\mathrm{qmm}$ ))

\begin{tabular}{|c|c|c|c|c|c|c|c|c|c|c|c|c|c|}
\hline & \multicolumn{13}{|c|}{ Frequency of cell division at the distance from the rot apex or cut surfare (at the time of observation) of: } \\
\hline & o & $0.5 \mathrm{~mm}$ & $1.0 \mathrm{~nm}$ & $1.5 \mathrm{~mm}$ & $2.0 \mathrm{~mm}$ & $2.5 \mathrm{~mm}$ & $3.0 \mathrm{~mm}$ & $3.5 \mathrm{~mm}$ & $4.0 \mathrm{m13}$ & $5.0 \mathrm{~mm}$ & $6.0 \mathrm{~mm}$ & $7.0 \mathrm{~mm}$ & $8.0 \mathrm{~mm}$ \\
\hline $\begin{array}{l}\text { Intact root } \\
\text { Aventige of } 4 \text { towts }^{2}\end{array}$ & - & $\begin{array}{l}21.88 \\
(.3 .54)\end{array}$ & $\begin{array}{c}104.3^{8} \\
(4.54)\end{array}$ & $\begin{array}{r}119.25 \\
(5.19)\end{array}$ & $\begin{array}{l}77.95 \\
(5.76)\end{array}$ & $\begin{array}{l}52.40 \\
(5.86)\end{array}$ & $\begin{array}{l}48.00 \\
(6 . \times 7)\end{array}$ & $\begin{array}{l}25.90 \\
(6.28)\end{array}$ & $\begin{array}{l}22.53 \\
(6.25)\end{array}$ & $\begin{array}{l}11.43 \\
(6.22)\end{array}$ & $\begin{array}{c}4.50 \\
(6.14)\end{array}$ & $\begin{array}{c}6.58 \\
(6.19)\end{array}$ & $\begin{array}{r}3.30 \\
(0.89)\end{array}$ \\
\hline $\begin{array}{l}\text { I mm decapitated root } \\
\text { Azerage of } 5 \text { roots }\end{array}$ & $\begin{array}{l}39 \cdot 4 \% \\
(4.30)\end{array}$ & $\begin{array}{l}82.08 \\
(5.6 y)\end{array}$ & $\begin{array}{l}75.50 \\
(6.44)\end{array}$ & $\begin{array}{l}65.36 \\
(6.82)\end{array}$ & $\begin{array}{l}3(1.62 \\
(6.99)\end{array}$ & $\begin{array}{l}34.04 \\
(\overline{7} . \overline{\mathbf{1}})\end{array}$ & $\begin{array}{l}20.14 \\
(6.90)\end{array}$ & - & $\begin{array}{l}9.94 \\
(6.99)\end{array}$ & $\begin{array}{c}7 \cdot 12 \\
(7 \cdot 13)\end{array}$ & $\begin{array}{c}4.3^{2} \\
\left(7.4^{6}\right)\end{array}$ & & \\
\hline $\begin{array}{l}3 \mathrm{~mm} \text { decapitated root } \\
\text { Avernge of } 5 \text { roots }\end{array}$ & $\begin{array}{l}22.14 \\
(5.25)\end{array}$ & $\begin{array}{l}11.16 \\
(5.63)\end{array}$ & $\begin{array}{c}6.94 \\
(5.68)\end{array}$ & $\begin{array}{r}6.94 \\
(5.81)\end{array}$ & $\begin{array}{r}6.86 \\
(5.81)\end{array}$ & - & $\begin{array}{l}3.94 \\
(5.83)\end{array}$ & & & & & & \\
\hline
\end{tabular}


$3 \mathrm{~mm}$ decapitated root to the point $3.0 \mathrm{~mm}$ in the intact root. Comparing these three curves it is seen that in the $3 \mathrm{~mm}$ decapitated root and the $1 \mathrm{~mm}$ decapitated root, the frequency of cell division is very small at the portions most contiguous to the surface of decapitation (namcly o), as a matter of course, and also at the portion $0.5 \mathrm{~mm}$ from the cut surface it is small.

in the next place I studied the frequency of cell division of the roots 7 hours after decapitation (as materials the roots, showing an intermediate rate of the elongation in Exp. XII, Table 3, were chosen). In this case (Table I2) the maximum point of the frequency of cell division in the intact root moved to the point $1.5 \mathrm{~mm}$ from the apex; as in the case of the roots 4 hours after decapitation, in the I $\mathrm{mm}$ decapitated root the frequency in the portion nearest to the cut surface is smail and the maximum point of frequency is at the point $0.5 \mathrm{~mm}$ from the cut surface; and in the $3 \mathrm{~mm}$ decapitated root, the portion nearest to the surface is the maximum of frequency, though the absolute value of it is very short.

The average elongation of the portion within $4 \mathrm{~mm}$ from the root apex, before the decapitation, during 7 hours after the decapitation, are as below: in the intact root, $I . \mathrm{I} \mathrm{nm}$; in the $I \mathrm{~mm}$ decapitated root, $0.9 \mathrm{~mm}$ and in the $3 \mathrm{~mm}$ decapitated root, $0.2 \mathrm{~mm}$. We may, therefore, put the point of $4.0 \mathrm{~mm}$ of the $\mathrm{I} \mathrm{mm}$ decapitated root to the point of $5.0 \mathrm{~mm}$ of the intact root; and the point of $1.0 \mathrm{~mm}$ of the $3 \mathrm{~mm}$ decapitated root, to the point $5.0 \mathrm{~mm}$ of the intact root, as shown in Fig. 2.

Comparing these three curves, we find that in the $1 \mathrm{~mm}$ decapitated root, the frequency of the point nearest to the cut surface is of course small, and the value at the maximum point is also less than that at the corresponding point in the intact root. It must be, therefore, recognized that the influence of cutting extended to this point namely $0.5 \mathrm{~mm}$ from the cut surface. The $3 \mathrm{~mm}$ decapitated root shows a curve nearly similar to the corresponding part of the curve of the intact root in this figure. But the najority of the results of the elongation of the region within $4 \mathrm{~mm}$ from the apex (at the beginning of the experiment) of the intact root, during 7 hours, is attributable rather to the elongation of the basipetal part of that region, namely near the portions 4 or $5 \mathrm{~mm}$ from the root apex, measured 7 hours after the operation. Therefore, the position of of the $3 \mathrm{~mm}$ decapitated root must be removed more to the leftward than shown in 


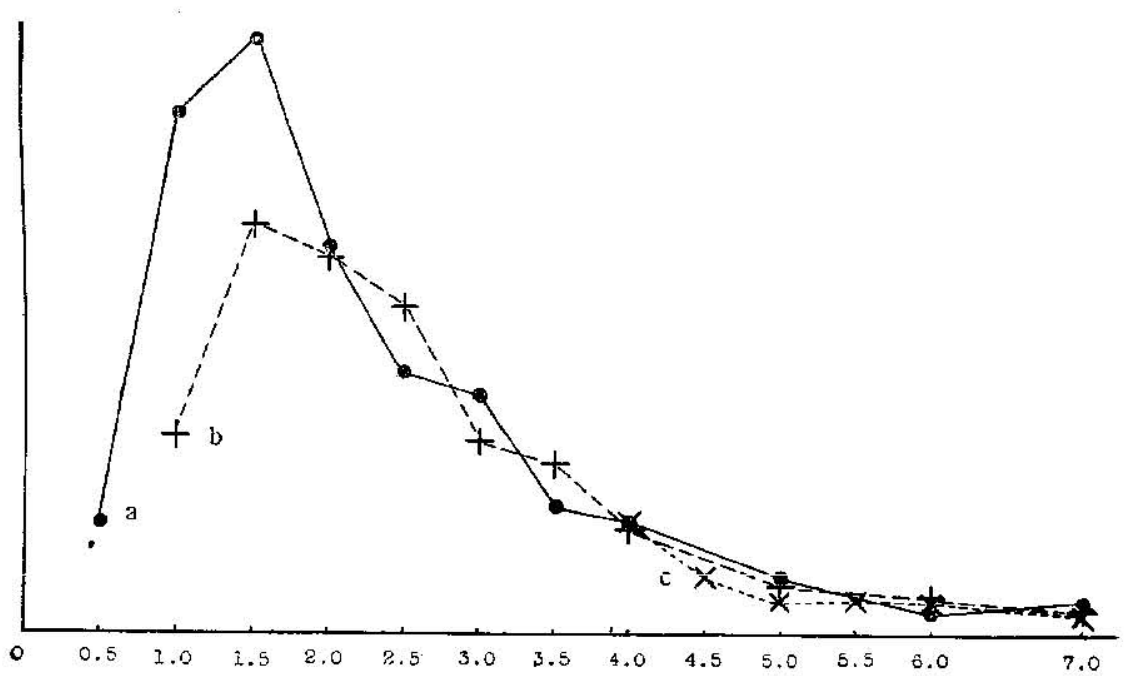

Fig. 2. Frequency of cell division of the decapitated roots ( 7 hours after decapitation), in comparison with that of the intact root. Ordinates represent the frequency of cell division; abscissi, distance in $\mathrm{mm}$ from the apex of the intact root, at the time of measurement. Curve a, the intact ront; b, the $1 \mathrm{~mm}$ decapitated root; $c$, the $3 \mathrm{~mm}$ decapitated root.

the figure; consequently, perhaps it may be true that the frequency of cell division in the root is less than that of the other two.

I did not test the frequency of cell division in the preparations of material more than 7 hours after the cutting, as the real state of the effect of cutting is likely to be fully seen in the two experiments above mentioned, also in fear that in a long time after the operation, besides the direct influence of cutting, there may appear the secondary factor as regeneration, which might disturb the observation.

\section{COMPARISON OF THE, CELL DIVISION ANT \\ THE CELL ELONGATION}

The elongation of the decapitated roots are retardated by the decapitation; on the other hand, there is found no tendency to accelerate the frequency of cell division by the decapitation, but, in general, it tends also rather to decrease; especially at the point nearest the cut surface the frequency is very minute.

As regards the influence upon the elongation, in the case 4 hours 
after the cutting, as the method of observation is to compare the length, which is the final result of elongation during 4 hours, the difference of elongation is still so small and not so remarkable.

Yet in the experiments more than 7 hours after the decapitation, we can recognize the influence of cutting more clearly.

However, regarding the frequency of cell division, we can see remarkable differences between them, already in the materials 4 hours after the cutting. The influence of cutting upon elongation extendes far from the cut (in the $3 \mathrm{~mm}$ decapitated root we could see the result of influence in the portion far more than $2 \mathrm{~mm}$ from the cut surface); on the contrary, the influence upon the cell division extends not so far: within $0.5 \mathrm{~mm}$ it is seen clearly but at a distance from the cut end of $1.0 \mathrm{~mm}$ less distinctly.

In short, the cutting decreases the frequency of cell division and at the same time hinders the elongation of cell. This fact is similar to the result of the inhibition upon the elongation of the root by means of gypsum, showing the retarding of cell division as well as cell elongation.

- Now we must consider the various influences from the conditions introduced by the operation of decapitation, upon the cell division, cell elongation or clongation of root tissue. It is hard to research the results of influences upon the cell division but it is relatively easy to examinc some infuences concerning the elongation of the cell or that of the root tissue. In the first place we must consider the influence resulting from the change of water content of the tissue.

\section{MEASUREMENT ON WATER CONTENT}

In the nature of the study, the measurement on water content was done in the region basipetal $4 \mathrm{~mm}$ from the root apex, namely in regions $\mathrm{B}$ and $\mathrm{C}$.

The material cultured in saw dust for 24 hours (Exps. VIII and IX, Table 2) was weighed (Table I3) and it was scen that there was no remarkable difference between the $\mathrm{I} \mathrm{mm}$ decapitated root and the intact root in fresh weight, water content and also the ratio $\frac{\text { water content }}{\text { dry weight }}$, and that the $4 \mathrm{~mm}$ decapitated root showed less values as to those points. It can be said, therefore, that the $4 \mathrm{~mm}$ decapitated 
roots were in the state of want of water. However, the materials discussed here are those 24 hours after the decapitation and show only the state of that time. In reality, the elongation of the cell is influenced in the majority of cases by the state of the root prior to that time. So we must research, in the next plan, the materials 7 hours after decapitation.

Table 13. Average water content of the decapitated root (in saw dust) measured about 24 hours after the operation (The unit of weight is $\mathrm{mg}$ )

\begin{tabular}{|c|c|c|c|c|c|}
\hline & & \multicolumn{2}{|c|}{ Intact roots } & \multicolumn{2}{|c|}{$\begin{array}{l}\text { Roots decaptitated at the } \\
\text { several points respectively } \\
\text { from the root apex: }\end{array}$} \\
\hline & & $\begin{array}{c}\text { Observed } \\
\text { value }\end{array}$ & $\begin{array}{l}\text { Relative } \\
\text { value }\end{array}$ & $\mathrm{I} \mathrm{mm}$ & $4 \mathrm{~mm}$ \\
\hline \multirow[t]{5}{*}{ Series 1} & No. of roots observed & 14 & 100 & 14 & 14 \\
\hline & Fresh weight & $41 \cdot 5$ & 100 & 100.7 & 90.6 \\
\hline & Dry weight & 2.32 & 100 & IOI. 2 & 99.1 \\
\hline & Water content & 39.2 & 100 & 100.5 & 88.5 \\
\hline & $\frac{\text { Water content }}{\text { Dry weight }}$ & $16.8 \%$ & 100 & $99 \cdot 3$ & 89.2 \\
\hline \multirow[t]{5}{*}{ Series 2} & No. of ruots observed & xi & & ro & 12 \\
\hline & Fresh weight & $3^{8.2}$ & 100 & 109.4 & 91.6 \\
\hline & Dry weight & 2.43 & 100 & 103.6 & $97 \cdot 1$ \\
\hline & Water content & $35 \cdot 7$ & 100 & 109.5 & 91.3 \\
\hline & $\frac{\text { Water content }}{\text { Dry weight }}$ & 14.72 & 100 & 100.7 & 94.0 \\
\hline \multirow[t]{4}{*}{ Average } & Fresh weight & 39.9 & 100 & 105.1 & $9 \mathbf{I} \cdot \mathbf{I}$ \\
\hline & Dry weight & $2.3^{8}$ & $100^{\circ}$ & 104.9 & $9^{6}, \mathbf{1}$ \\
\hline & Water content & $37 \cdot 5$ & 100 & 105.0 & 39.9 \\
\hline & $\frac{\text { Water content }}{\text { Dry weight }}$ & 15.60 & 100 & 100.0 & 91.6 \\
\hline
\end{tabular}

Measuring the materials 7 hours after decapitation (Fxp. XI, XIII and XIV in Table 3) we can find that regarding water content and the ratio $\frac{\text { water content }}{\text { dry weight }}$ the $I \mathrm{~mm}$ decapitated roots are nearly equal 
to the intact root or a little less than that, and the $4 \mathrm{~mm}$ decapitated root and $3 \mathrm{~mm}$ decapitated root are less than the intact root (Table I4).

Table I4. Average water content of the decapitated root (in saw dust) measured 7 hours after the operation (The unit of weight is $\mathrm{mg}$ )

\begin{tabular}{|c|c|c|c|c|c|c|}
\hline & & \multicolumn{2}{|c|}{ Intact roots } & \multicolumn{3}{|c|}{$\begin{array}{l}\text { Roots decapitated at the several } \\
\text { points respertively from the } \\
\text { root apex: }\end{array}$} \\
\hline & & $\begin{array}{c}\text { Observed } \\
\text { value }\end{array}$ & $\begin{array}{c}\text { Relative } \\
\text { value }\end{array}$ & I $\mathrm{mm}$ & $3 \mathrm{~mm}$ & $4 \mathrm{~mm}$ \\
\hline \multirow[t]{5}{*}{ Series $\mathbf{I}$} & No. of roots observed & 13 & & 12 & I4 & $\mathbf{I}_{3}$ \\
\hline & Fresh weight & I5.I & I00 & 94.0 & 90.7 & $87 \cdot 4$ \\
\hline & Dry weight & 1.07 & 100 & 93.5 & 100.0 & 107.5 \\
\hline & Water content & 14.0 & 100 & 94.3 & 90.0 & 86.4 \\
\hline & $\frac{\text { Water content }}{\text { Dry wright }}$ & $\mathbf{r}_{3} .08$ & 100 & 100.6 & 90.3 & 80.2 \\
\hline \multirow[t]{5}{*}{ Serics 2} & No. of roots obscrved & I 2 & & 12 & $\mathrm{I} 2$ & 12 \\
\hline & Fresh weight & 17.0 & 100 & $105 \cdot 3$ & 94.1 & 81.2 \\
\hline & Dry weight & 1.02 & 100 & I11.8 & 102.0 & 89.2 \\
\hline & Water content & 15.9 & 100 & 105.0 & 94.3 & 8I.I \\
\hline & $\frac{\text { Water content }}{\text { Dry weight }}$ & I 5.59 & 100 & 94.1 & 92.6 & 90.6 \\
\hline \multirow[t]{5}{*}{ Series 3} & No. of roots observed & 12 & & 12 & - & 12 \\
\hline & Fresh weight & 16.1 & 100 & 87.0 & 一 & 82.6 \\
\hline & Dry weight & 1.08 & 100 & 86.1 & - & 88.0 \\
\hline & Water content & 15.0 & 100 & $87 \cdot 3$ & - & 82.0 \\
\hline & $\frac{\text { Water content }}{\text { Dry weight }}$ & 13.87 & 100 & 101.2 & - & $93 \cdot 7$ \\
\hline \multirow[t]{4}{*}{ Average } & Fresh weight & 16.1 & IOO & $95 \cdot 4$ & 92.4 & $83 \cdot 7$ \\
\hline & Dry weight & 1.06 & IOO & $97 \cdot 1$ & Ior.o & 94.9 \\
\hline & Water content & 15.0 & 100 & $95 \cdot 5$ & 92.2 & $8_{3.2}$ \\
\hline & $\frac{\text { Water content }}{\text { Dry weight }}$ & 14.18 & 100 & 98.6 & 91.5 & 88.2 \\
\hline
\end{tabular}


In the materials 4 hours after decapitation (Exp. XVI, XVII and XVIII in Table 4), also we can see the smallness in the value of water content and its ratio to the dry weight of the $3 \mathrm{~mm}$ decapitated roots and the $4 \mathrm{~mm}$ decapitated roots; the $\mathrm{I} \mathrm{mm}$ decapitated roots are also small in a slight degree (Table I5).

Table 15. Average water content of the decapitated root (in saw dust) measured 4 hours after the operation (The unit of weight is $\mathrm{mg}$ )

\begin{tabular}{|c|c|c|c|c|c|c|}
\hline & & \multicolumn{2}{|c|}{ Intact roots } & \multicolumn{3}{|c|}{$\begin{array}{l}\text { Koots decapitated at the several } \\
\text { points respectively from the } \\
\text { root apex: }\end{array}$} \\
\hline & & $\begin{array}{l}\text { Observed } \\
\text { value }\end{array}$ & $\begin{array}{c}\text { Relative } \\
\text { value }\end{array}$ & $1 \mathrm{~mm}$ & $3 \mathrm{~mm}$ & $4 \mathrm{~mm}$ \\
\hline \multirow[t]{5}{*}{ Series I } & No. of roots observed & IO & & IO & 10 & Io \\
\hline & Fresh weight & $9 \cdot 9$ & 100 & 100.0 & 88.9 & 89.9 \\
\hline & Dry weight & 0.75 & 100 & 101.3 & $93 \cdot 3$ & 100.0 \\
\hline & Water content & 9.2 & 100 & 98.9 & 88.0 & $\Leftrightarrow 9.1$ \\
\hline & $\frac{\text { Water content }}{\text { Dry weight }}$ & 12.20 & 100 & 98.4 & 94.4 & $89 \cdot 3$ \\
\hline \multirow[t]{5}{*}{ Series 2} & No. of roots observed & 14 & & I6 & I 6 & 14 \\
\hline & Fresh weight & I3.4 & 100 & 98.5 & $84 \cdot 3$ & $84 \cdot 3$ \\
\hline & Water content & 0.98 & 100 & IOI.O & 95.9 & 96.9 \\
\hline & Dry weight & $\mathrm{I} 2.4$ & 100 & 90.3 & 83.9 & 83.9 \\
\hline & $\begin{array}{l}\text { Water content } \\
\text { Iry weight }\end{array}$ & 12.66 & Ios & 97.1 & $87 \cdot 3$ & 86.2 \\
\hline \multirow[t]{5}{*}{ Series 3} & No. of roots observed & I I & & 9 & II & II \\
\hline & Fresh weight & 16.1 & 100 & 93.8 & 87.6 & 37.6 \\
\hline & Dry weight & 1.24 & 100 & 98.4 & $9 \mathfrak{B} \cdot 4$ & IOI.6 \\
\hline & Water content & 14.8 & $1 \infty$ & 93.9 & 86.5 & 67.2 \\
\hline & $\frac{\text { Water content }}{\text { Dry weight }}$ & 11.89 & 100 & 95.4 & 83.0 & 85.6 \\
\hline \multirow[t]{4}{*}{ Average } & Fresh weight & 13.1 & 100 & $97 \cdot 4$ & 86.9 & $87 \cdot 3$ \\
\hline & Dry weight & 0.99 & 100 & 100.2 & 95.9 & 99.5 \\
\hline & Water content & 12.1 & 100 & $94 \cdot 3$ & 36.1 & 86.7 \\
\hline & $\frac{\text { Water content }}{\text { Dry weigh }}$ & 12.25 & 100 & 97.0 & 89.9 & 87.0 \\
\hline
\end{tabular}


The above mentioned measurements show that the decapitated roots are in want of water. The lack of water probably has its influence intensely upon the cell elongation, thenceforth.

Next, I studied the materials of experiments in water. Materials 24 hours after decapitation (Exp. XX, XXI, XXII and XXIII in Table 5) do not show any definite visible differences among the different kinds of roots, except that the $4 \mathrm{~mm}$ decapitated root is a little less in the ratio $\frac{\text { water content }}{\text { dry weight }}$, compared to the others (Table I6).

Table 16. Average water content of the decapitated root (in water) measured about 24 hours after the operation (The unit of weight is $\mathrm{mg}$ )

\begin{tabular}{|c|c|c|c|c|c|c|}
\hline & & \multicolumn{2}{|c|}{ Intact roots } & \multicolumn{3}{|c|}{$\begin{array}{l}\text { Ronts decapitated at the several } \\
\text { points respectively from the } \\
\text { root apex: }\end{array}$} \\
\hline & & $\begin{array}{c}\text { Observed } \\
\text { value }\end{array}$ & $\begin{array}{c}\text { Relative } \\
\text { value }\end{array}$ & I $\mathrm{mm}$ & $3 \mathrm{~mm}$ & $4 \mathrm{~mm}$ \\
\hline \multirow[t]{5}{*}{ Series I } & No. of roots observed & $\delta$ & & 7 & 8 & I5 \\
\hline & Fresh weight & 28.5 & 100 & $9^{8.2}$ & IO2.8 & Iç3.8 \\
\hline & I)ry weight & 1.65 & 100 & 97.0 & 104.8 & 112.7 \\
\hline & Water content & 26.8 & 100 & 98.5 & 102.6 & 108.6 \\
\hline & $\frac{\text { Water content }}{\text { Dry weight }}$ & 16.25 & 100 & 108.6 & $97 \cdot 4$ & 96.1 \\
\hline \multirow[t]{5}{*}{ Series 2} & No. of roots observed & 16 & & 13 & 14 & I6 \\
\hline & Fresh weight & $3 \mathrm{r} . \mathrm{I}$ & 100 & 95.8 & 103.9 & $87 \cdot 5$ \\
\hline & Dry weight & 2.02 & 100 & 93.6 & 102.0 & 89.6 \\
\hline & Water content & 29.1 & 100 & 95.9 & 104.1 & $37 \cdot 3$ \\
\hline & $\frac{\text { Watcr content }}{\text { Dry weight }}$ & I $4.4 \mathrm{I}$ & 100 & 102.5 & 102.1 & 97.6 \\
\hline \multirow[t]{5}{*}{ Series 3} & No. of roots observed & I3 & & 14 & - & 15 \\
\hline & Fresh weight & $35 \cdot 5$ & 100 & $104 \cdot 3$ & - & $8 r .8$ \\
\hline & Dry weight & 2.16 & 100 & 104.2 & 一 & 86.6 \\
\hline & Water content & $33 \cdot 0$ & 100 & $10.3 \cdot 9$ & - & 81.5 \\
\hline & $\frac{\text { Water content }}{\text { Dry weight }}$ & I5.25 & 100 & 99.9 & 一 & 93.2 \\
\hline
\end{tabular}




\begin{tabular}{|c|c|c|c|c|c|c|}
\hline \multirow[t]{5}{*}{ Series 4} & No. of roots observed & 13 & & 12 & - & II \\
\hline & Fresh weight & 30.9 & I $\infty 0$ & 91.3 & - & $97 \cdot x$ \\
\hline & Dry weight & 1.97 & 100 & 91.9 & - & 98.5 \\
\hline & Water content & 28.9 & 100 & $9^{1} \cdot 3$ & - & 96.9 \\
\hline & $\begin{array}{c}\text { Water content } \\
\text { Dry weight }\end{array}$ & $\mathbf{1} 4.68$ & 100 & $99 \cdot 4$ & - & 98.6 \\
\hline \multirow[t]{4}{*}{ Average } & Fresh weight & 31.4 & 100 & $97 \cdot 4$ & 103.4 & 93.8 \\
\hline & Dry weight & 1.95 & 100 & 96.7 & $103 \cdot 4$ & 96.9 \\
\hline & Water content & $29 \cdot 5$ & 100 & $97 \cdot 4$ & 103.4 & 93.6 \\
\hline & $\frac{\text { Water content }}{\text { Dry weight }}$ & 15.15 & 100 & 102.6 & 99.8 & 96.4 \\
\hline
\end{tabular}

Results of measurements on the materials 7 hours after decapitation (Exp. XXIV, XXV and XXVI in Table 6) is shown in Table 17. As we can see there, in two cases, the $4 \mathrm{~mm}$ decapitated root is rather larger than others in the ratio $\frac{\text { water content }}{\text { dry weight }}$ it seemingly promises the superfluous or real elongation of the root, thenceforth.

Table 17. Average water content of the decapitated root (in water) measured 7 hours after the operation (The unit of weight is $\mathrm{mg}$ )

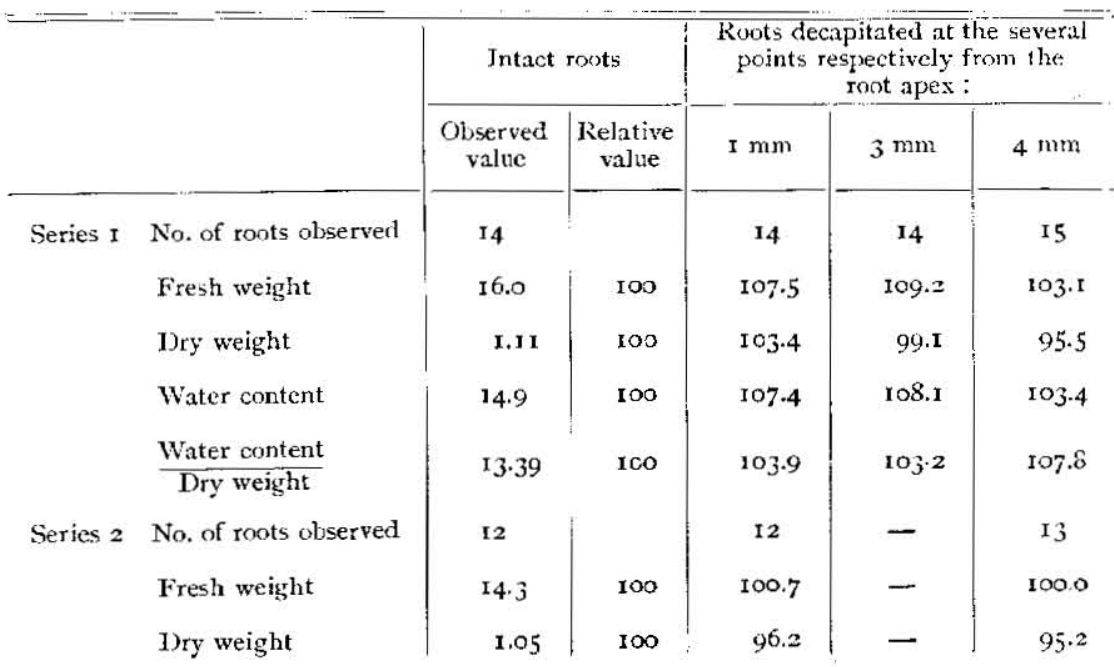




\begin{tabular}{|c|c|c|c|c|c|c|}
\hline & Water content & $13 \cdot 3$ & 100 & 100.8 & - & 100.0 \\
\hline & $\frac{\text { Water content }}{\text { Dry wcight }}$ & 12.63 & 100 & 105.2 & - & 105.5 \\
\hline \multirow[t]{5}{*}{ Serjes 3} & No. of routs observed & 12 & & $\mathrm{I}_{3}$ & 12 & 12 \\
\hline & Fresh weight & 16.1 & 100 & 100.0 & 93.8 & 91.9 \\
\hline & Dry weight & I.18 & 100 & 100.0 & IOI. 7 & 93.2 \\
\hline & Water content & 14.9 & 100 & 100.7 & 98.7 & 91.9 \\
\hline & $\frac{\text { Water content }}{\text { Bry weight }}$ & 12.61 & 100 & 100.2 & $97 \cdot 3$ & 99.0 \\
\hline \multirow{4}{*}{ Average } & Fresh weight & 15.5 & 100 & 102.7 & 104.0 & 98.3 \\
\hline & Dry weight & I.I I & 100 & 99.9 & 100.4 & 94.6 \\
\hline & Water content & 14.4 & 100 & 103.0 & 103.4 & 98.4 \\
\hline & $\frac{W_{\text {ater content }}}{\text { Dry weight }}$ & 12.86 & 100 & 103.1 & 100.3 & 104. I \\
\hline
\end{tabular}

Materials 4 hours after decapitation (Exp. XXVII, XXVIII and $\mathrm{XXIX}$ in Table 7) wcre weighed, and the results are shown in Table I 8 . In two cases of these, the $4 \mathrm{~mm}$ decapitated roots are large in the ratio water content dry weight . This must be also favourable for the roots to grow superfluously, henceforward.

Table 18. Average water content of the decapitated root (in water) measured 4 hours after the operation (The unit of weight is $\mathrm{mg}$ )

\begin{tabular}{|c|c|c|c|c|c|c|}
\hline & \multirow[t]{2}{*}{$+\cdots$} & \multicolumn{2}{|c|}{ Intact roots } & \multicolumn{3}{|c|}{$\begin{array}{l}\text { Roots decapitated at the several } \\
\text { points respectively from the } \\
\text { root apex: }\end{array}$} \\
\hline & & $\begin{array}{l}\text { Observed } \\
\text { value }\end{array}$ & $\begin{array}{c}\text { Relative } \\
\text { value }\end{array}$ & $1 \mathrm{~mm}$ & $3 \mathrm{~mm}$ & $4 \mathrm{~mm}$ \\
\hline \multirow[t]{5}{*}{ Śries I } & No. of roots observed & II & & 13 & 12 & I 2 \\
\hline & Fresh wcight & $13 \cdot 3$ & 100 & 104.5 & 108.3 & 103.8 \\
\hline & Dry weight & I.OI & 100 & 106.9 & 105.9 & 95.0 \\
\hline & Water content & 12.3 & 100 & IO4. I & Iô. I & 104.9 \\
\hline & $\frac{\text { Water content }}{\text { Dry weight }}$ & 12.13 & 100 & 97.0 & 102.6 & 110.3 \\
\hline
\end{tabular}




\begin{tabular}{|c|c|c|c|c|c|c|}
\hline \multirow[t]{5}{*}{ Series 2} & No. of roots observed & I4 & & 14 & 14 & 14 \\
\hline & Fresh weight & 12.6 & 100 & 107.9 & 106.3 & 107.1 \\
\hline & Dry weight & 0.95 & 100 & 108.4 & $1 \mathrm{O}_{4} .2$ & 108.4 \\
\hline & Water content & II. 7 & 100 & 106.8 & 106.0 & 106.3 \\
\hline & $\frac{\text { Water content }}{\text { Dry weight }}$ & 12.27 & 100 & $99 . z$ & ICI.7 & 90.0 \\
\hline \multirow[t]{5}{*}{ Series 3} & No. of roots observed & 13 & & $I_{3}$ & $I_{3} 3$ & $\mathbf{I} 3$ \\
\hline & Fresh weight & 13.5 & 100 & 103.0 & I02.2 & 104.4 \\
\hline & Dry weight & I.03 & 100 & 104.9 & 102.9 & ror.9 \\
\hline & Water content & 12.4 & 100 & 103.2 & I02.4 & 104.3 \\
\hline & $\begin{array}{c}\text { Water content } \\
\text { Dry weight }\end{array}$ & 12.07 & 100 & 98.8 & $99 \cdot 4$ & 102.5 \\
\hline \multirow[t]{4}{*}{ Average } & Fresh weight & 13.1 & 100 & I05.I & 105.6 & 105.1 \\
\hline & Dry weight & 1.00 & 100 & 106.7 & $104 \cdot 3$ & IOI.8 \\
\hline & Water content & 12.1 & 100 & 104.7 & 105.5 & 105.5 \\
\hline & $\begin{array}{l}\text { Water content } \\
\text { Dry weight }\end{array}$ & 12.17 & 100 & 98.3 & 101.2 & 10.3 .9 \\
\hline
\end{tabular}

As a whole, the $4 \mathrm{~mm}$ decapitated roots, in saw dust, sl:ow the ratio water content in small amount; but as to those in water, it is not necessarily the case, namely, in some cases the ratio $\frac{\text { water content }}{\text { dry weight }}$ in the $4 \mathrm{~mm}$ decapitated root is larger than the intact roots.

Now, we see that there are some differences in regard to the water between the materials in saw dust and in water. Therefore, when we discuss the length of the cell, measured in the decapitated root, we ought to consider, beside the primary effect of the cutting, also the secondary influence of the water absorbed upon the growth of the cell. At any rate, the fact is sure that the shortness of elongation of the decapitated root is due to the shortness of the elongation of the cell.

\section{EFFECTS OF PRICKING ON THE ROOT TISSUE}

In order to give an unusual condition upon the root, instead of cutting, I pricked it and examined the result of the pricking influenced 
upon the elongation of the normal part of the root. The method applied here is as follows: after pricking the roots uniformly about I 5 times in the respective regions with a fine glass needle (dianceter:

Table 19. Elongation of the pricked root during 24 hours after the operation

\begin{tabular}{|c|c|c|c|c|c|c|}
\hline & \multicolumn{2}{|c|}{ Intact roots } & \multicolumn{4}{|c|}{$\begin{array}{l}\text { Koots pricked at the several portions between } \\
\text { the respective points from the root apex: }\end{array}$} \\
\hline & $\begin{array}{l}\text { Observed } \\
\text { value } \\
\text { (in mm) }\end{array}$ & \multirow[t]{2}{*}{$\begin{array}{c}\text { Relative } \\
\text { value } \\
\ldots\end{array}$} & $0.4 \mathrm{~mm}$ & $4.5 \mathrm{~mm}$ & $5.10 \mathrm{~mm}$ & $10-15 \mathrm{~mm}$ \\
\hline $\begin{array}{l}\text { No. of roots ob- } \\
\text { served }\end{array}$ & 8 & & 9 & 9 & 10 & 9 \\
\hline \multirow{3}{*}{$\begin{array}{l}\text { Portion of which } \\
\text { the elongation is } \\
\text { observed }\end{array}$} & 14.45 & 100 & 199 & 54.2 & 37.2 & 21.2 \\
\hline & 3.94 & 100 & 98.0 & 20.1 & $45 \cdot 9$ & $3^{3.8}$ \\
\hline & 5.63 & 100 & 77.4 & 52.2 & 10.5 & 26.8 \\
\hline
\end{tabular}

Table 20. Elongation of the pricked root during 24 hours after the operation

\begin{tabular}{|c|c|c|c|c|c|c|}
\hline & \multicolumn{2}{|c|}{ Intact roots } & \multicolumn{4}{|c|}{$\begin{array}{l}\text { Roots pricked at the several portions between } \\
\text { the respective points from the root apex: }\end{array}$} \\
\hline & $\begin{array}{c}\text { Observed } \\
\text { value } \\
\text { (in } \mathrm{mm} \text { ) } \\
\end{array}$ & $\begin{array}{l}\text { Relative } \\
\text { value }\end{array}$ & O- $\mathrm{I} \mathrm{mm}$ & $\mathrm{I} \cdot \mathbf{2} \mathrm{mm}$ & $3-4 \mathrm{~mm}$ & $5.6 \mathrm{~mm}$ \\
\hline $\begin{array}{l}\text { Series I } \\
\text { Yis. of roots observed }\end{array}$ & $1:$ & & 9 & 72 & $\pi$ & IT \\
\hline \multirow{3}{*}{$\begin{array}{l}\text { Portion of which } \\
\text { the elongation is } \\
\text { olserved }\end{array}$} & $9 \cdot 3^{\circ}$ & 100 & 77.7 & 90.6 & 39.6 & 65.5 \\
\hline & $3 \cdot 71$ & IOO & 96.5 & 111.3 & $87 \cdot 3$ & $5^{3.2}$ \\
\hline & 5.51 & 100 & $93 \cdot 3$ & IOI.I & 86.2 & 34.8 \\
\hline $\begin{array}{l}\text { Series } 2 \\
\text { No. of roots obscrved }\end{array}$ & 10 & & I $\mathbf{I}$ & II & I I & I I \\
\hline \multirow{3}{*}{$\begin{array}{l}\text { lortion of which } \\
\text { the elongation is }\left\{\begin{array}{l}\text { A } \\
\text { observed }\end{array}\right. \\
\text { C }\end{array}$} & 10.99 & 100 & 96.8 & 75.6 & 37.2 & 68.1 \\
\hline & $3 \cdot 72$ & 100 & 94.4 & 102.4 & 63.3 & 51.9 \\
\hline & 4.73 & 100 & 97.0 & 108.9 & 80.4 & 21.8 \\
\hline \multirow{3}{*}{$\begin{array}{l}\text { Average } \\
\text { Portion of which } \\
\text { the elongation is } \\
\text { observed }\end{array}$} & 10.15 & 100 & 58.3 & $\S_{3} .1$ & 38.4 & 66.8 \\
\hline & $3.7^{2}$ & 100 & 95.5 & $1 \mathrm{c} 6.9$ & 73.1 & 5.5 .1 \\
\hline & 5.12 & 100 & 95.2 & 105.0 & $37 \cdot 3$ & 28.3 \\
\hline
\end{tabular}


ca. $\frac{20}{100} \mathrm{~mm}$ ), they were planted in moist saw dust. After 24 hours, the elongation of each region was measured (Table I9 and 20). The results of the experiments are similar, in general, to those of decapitated root; the elongation of the portions near the position of pricking are short. After all, this must be attributed to the distraction of some cells and the change of turgor of irritated cells by pricking, and it is the similar cause as in the case of the decapitation. In this case the influence of pricking does not extend to so far a distance as in the case of cutting, and the reason of it may depend on the smallness of the change of water relation in this, in comparison to that case.

\section{EFFECTS OF PRESSURE GIVEN ON A PART OF TIIE ROOT}

Instead of cutting or pricking, I gave pressure to a root so as to change the turgor of that portion.

A piece of fine thread was tied around a distance $3 \mathrm{~mm}$ from root apex, and tightened for a while (but not too tightly or the rool would be cut off at that portion); that portion was seen to be depressed a little and at the same time the surface of that part moistened slightly, then the thread was untied. Beside these roots, roots decapitated at

Table 21. Flongation of the squeezed root during 24 hours after the operation

\begin{tabular}{|c|c|c|c|c|}
\hline \multirow{2}{*}{$\begin{array}{l}\text { Portion of which } \\
\text { the elongation } \\
\text { is olsserved }\end{array}$} & \multicolumn{2}{|c|}{ Intact roots } & \multirow{2}{*}{ Squeezed roots } & \multirow{2}{*}{$\begin{array}{l}3 \mathrm{~mm} \text { decsipitated } \\
\text { roots }\end{array}$} \\
\hline & $\begin{array}{l}\text { Observed value } \\
\text { (in } \mathrm{mm} \text { ) }\end{array}$ & Relative value & & \\
\hline I3 & $5.21 \quad(7)^{\mathrm{r}}$ & 100 & $85.6 \quad(8)$ & $67.0(10)$ \\
\hline C & $7.27(11)$ & 100 & $89.8(12)$ & $74 \cdot 3(12)$ \\
\hline
\end{tabular}

The figure given in brackets is the number of roots observed.

$3 \mathrm{~mm}$ from the root apex, and the intact roots were embedded in saw dust; after $23 \frac{1}{2}$ hours the elongation of these roots were measured. The results are as shown in Table $2 \mathrm{r}$, namely in $\mathrm{C}$ region and $\mathrm{B}$ region, the squeezed root elongates to less extent ${ }^{7}$ than the intact root, though the elongation of the former is not so little as the $3 \mathrm{~mm}$

7 JANSE (1926, 1927) hindered the clongation of the root by pressing it between wet fingers. 
decapitated root shows. Perhaps the smallness of elongation of the squeezed root may be attributed to the destraction or the diminution of turgor of the cells.

\section{GENERAL CONCLUSIONS}

The principal object of the study is to see the correlation between the cell division and cell elongation, and not to know the detail of the cell division and elongation in every portion of the given material. So, as it is convenient to simplify the work yet to fulfil the expected purpose, I divided the root tip at $4 \mathrm{~mm}$ from the apex, and in the portion from that point up to basipetal, I studied mainly the elongation of the cell and the tissue, and in the portion from the point to the apex, I observed the cell division.

To sum up the results, we can find that the cutting diminishes the frequency of cell division, and at the same time shortens the elongation of the cells. But there must be consideration on the results of the investigation, whether those facts are the result influenced directly by the inhibition of further elongation of the root by cutting of the tip, or not. Cutting with even the best sharpened razor, pressure on the portion to be cut can not be avoided. When the root is cut in water, as I did, it can not be seen, but if it is being done in the air we can see that the gloss is off the surface of the portion of root most contiguous to the cut surface and it becomes dull and transparent, and the surface becomes moistened to a slight degrce. These phenomena are seen also in the root pricked, namely on the surface near the point of pricking, there appears a small fine strip, which the gloss is taken off and becomes dull and transparent, running parallel to the long axis of the root. And in the squeezed root, as in the case of the cut root, the taking off of the gloss, turning dull and transparent and the moistening of the surface are seen ${ }^{8}$. On the other hand, by cutting we can see that the surface of the cut is wet with moisture from the tissue of the root. Perhaps those abnomal phenomena may also happen when the root is cut in water, as in the cases of our experiments. Moreover, from the measuring the water content and the difference between the results of experiments in saw dust and in water, we can generally say that the de-

8 cf. JANSr, 1926, 1927. 
capitated roots in saw dust are losing the water from the cut surface. Putting these facts together we may consider that the cutting or injuring causes the change of water content in the tissue or of the turgor. Therefore, at least a part of the cause of the diminution of the elongation of tissue or cells of decapitated roots is due to the inhibition of cell clongation by the diminution of turgor. But it is questionable in this case whether it is the whole of the cause of that, or not. On the other hand it was observed that the cell division is hindered by the cutting, on the portion near the cut surface. I have obscrved in my previous study (1931) that the frequency of cell division was hindered by diminution of turgor of the root by the use of sugar solution. Probably also in this case, it must be one of the causes of the hindering of ccll division, that the diminution of turgor has influenced it either directly, or indirectly, through the effect of it upon the cell clongation. Namely the presence of conditions diminishing the turgor of the cell seems to cause the hindering of the cell division. Yet it is not of importance to discuss here whether the cause effects directly or indirectly, or in these two ways side by side.

In short, in case of inhibiting the elongation of the root tip by decapitation, the cell division and cell elongation are hindered at the same time, as in the cases of inhibiting the growth of the root by means of gypsum or sugar solusion.

It is obvious that after a long time there may be the formation of a callus or adventive root at the place of cutting or that in the neighbourhood to it, for the sake of that, the regenerative activity of tissues must induce the cell division; but this must be consiclered rather the appearance of secondary phenomenon caused by injuring. The point of view of this study is to see the direct relation of cell civision and elongation in the root tissue itself, inhibited from the growth; therefore we are to deal with only the primary results of cutting, in our case. In other words, the correlation of growth and cell division or tissue differentiation is mingled in complicated connection of several direct or indirect phenomena, therefore, these problems must be considered carefully and analytically, lest one should reach an unexpected and conflicting conclusion. It is regrettable that one is liable to get the true phase of phenomenon, concerning these problems of differentiation of tissue and growth, from considering only the final state which has resulted from the phenomenon during a long time. One must inquire into the problems as analytically as possible. 


\section{XI, SUMMARY}

I) The writer observed the relation between cell division and cell elongation in the decapitated roots. And in order to simplify the study the cell division was studied chiefly in portions within $4 \mathrm{~mm}$ from the root apex and the elongation in the portions basipetal from that point.

2) Measuring the roots cultivated in saw dust, it was found that the elongation of the portions besipetal from the $4 \mathrm{~mm}$ point of the roots decapitated at $3 \mathrm{~mm}$ or $4 \mathrm{~mm}$ from the root apex is less than the intact root; and that the I $\mathrm{mm}$ decapitated roots, 24 hours after decapitation, elongate rather longer than the intact roots (control), yet the I mm decapitated roots, 4 hours or 7 hours after the cutting, elongate in a still lesser degree, compared with the intact roots.

Next, measuring the portion within $4 \mathrm{~mm}$ from the root apex, it was seen that the elongation of all the decapitated roots was always less than the intact root.

In the cases of experiments of materials cultured in water, it often happened that decapitated roots clongate longer than the intact roots, especially concerning the portion within $4 \mathrm{mn}$ from the root apex, the elongation of the $1 \mathrm{~mm}$ decapitated root was always Ionger than that of the intact root. However, this is probably to be attributed to the disturbance of the normal elongation, by superfluous stretching, caused by the excess of water.

3) Putting together the results of measuring the water content of the portion of root, on which the elongation was observed, and other several experiments, it is likely to be assumed that by cutting or by other analogous operations the water content or turgor of the portion is mindered, and this must be one of causes inhibiting the elongation.

4) The cell lengths measured in the positions basipetal from the $4 \mathrm{~mm}$ point, run parallel to the rate of elongation of corresponding portions.

5) Diminution of the frequency of cell division is seen at the portion near the cut surface.

6) What is the cause of the diminution of cell elongation and cell division, in the decapitated roots, is beside the question in our case, yet the diminuent of the frequency of cell division as well as retardation of elongation of cells go together side by side. And this 
result is parallel with the cases of inhibition of growth of the root treated by gypum or sugar solution.

7) In considering the final results only of such experiments one may come to an erroneous conclusion, because there are several related indirect phenomena such as the formation of calli or adventive roots etc., besides the direct effects of cutting upon the division and elongation of cells, which is the only question which should be analysed here.

\section{LITERATURE CITED}

1. BüNninc; E., 192\&, Zur Physiologie des Wachstums und der Reizbewegungen der Wurzeln. Planta $5: 635-659$.

2. Frrtsch, G., ro84, Zur Kenutnis der geotropischen Keizharkeit der Wurzelspitze. Ber. d. D. Bot. Ges. $2: 248-255$.

3. Jaxse, J. M., I926, On new phenomena caused by irritation of roots. Proc. K. Akad. Wet. Amsterd. 29:834:\$42 (Bot. Centralbl. 10: 10.11, 1927).

4. - - 1927, Eine neuc Einteilung der Pflanzenbewegungen. Flora N. F. 22: 1-32.

5. Kojıмn, H., 1928, On the relation between cell division and elongation in the root of Vicia Fata. Jour. Dept. Agric. Kyushu Imp. Univ. $2: 75-91$.

6. - - 1931, Division, growth and differentiation of cells in the root of Vicia Faba artificially inhibited from forther elongation. Ibid. 3:121-147.

7. MoLisch, IL, $188_{3}$, Leber das Längenwachstum geköpfter und unverletzter Wurzeln. Ber. d. D. Bot. Ges. $1: 362-366$.

8. Prkakik, J., ז927, Leber den Einfluss der Röntgenstrahiten auf die Kern- und Zellteilung bei Wurzelspitzen von Iicin Fabo. Planta 4:299-357.

9. Pfafrer, W., Physiology of plants. Vol. II. Oxford, 1903.

ro. Seitér.r, O., 1923, Wachstumsmessungen an Knospen und Vegetationspunkten. Verhandl. d. Naturlich. Ges. in Basel. 34:41-68 (Cit. by PFkaknk, 1927).

II. Wiesver, J., I68I, Thas Bewegungsvermögen der Fflanzen. Wien, Pp. 2 I8 (Rot. Centrallil. $9: 137-154,1882$ ).

12. --, 1884, Untersuchungen über die Wachstumsbewegungen der Wurzeln. Sitzber. d. K. Akad. d. Wiss. Wien, Math.-Physik. Cl. 89:223-302 (Bot. Centralbl. 20:4-8, 1884). 